\title{
The geography of venture capital and entrepreneurial ventures' demand for external equity ${ }^{\text {मै }}$
}

\author{
Massimo G. Colombo ${ }^{\mathrm{a}}$, Diego D'Adda ${ }^{\mathrm{b}}$, Anita Quas, ${ }^{\mathrm{c}, *}$ \\ ${ }^{\text {a }}$ Politecnico di Milano, Italy \\ ${ }^{\mathrm{b}}$ Università Politecnica delle Marche, Italy \\ ${ }^{\mathrm{c}}$ EMLYON Business School - Department of Economics, Finance and Control, France
}

\section{A R T I C L E I N F O}

\section{Keywords:}

Entrepreneurial ventures

Venture capital hubs

Demand for external equity

Geographic distance

\begin{abstract}
A B S T R A C T
In this paper, we study how the geography of venture capital (VC) and the location of entrepreneurial ventures affect the propensity of the latter to seek external equity financing. We analyse a sample of 533 European hightech entrepreneurial ventures and examine their external equity-seeking behaviour in the 1984-2009 period. We find that ventures are more likely to seek external equity when the local availability of VC is higher, whereas the level of competition of the local VC market plays a negligible role. The stimulating effect of the availability of VC on the demand for external equity rapidly decreases with distance and vanishes at approximately $250 \mathrm{~km}$. It also vanishes when national borders are crossed, except for countries at close cultural and institutional distance. Moreover, the distance decay of the stimulating effect of the availability of VC varies with the characteristics of prospective VC investors, namely, their private or public ownership and governance, and their reputation. These results have important implications for the policy that European countries and the European Commission should implement to foster the demand for VC by entrepreneurial ventures, thereby improving the functioning of the VC market in Europe.
\end{abstract}

\section{Introduction}

Venture Capital (VC) investors are considered a fundamental source of finance for entrepreneurial ventures (Gompers and Lerner, 2001; Gorman and Sahlman, 1989; Kaplan and Strömberg, 2001; Sapienza, 1992). However, the number of VC-backed companies is small: in 2016, only 3134 companies in Europe (source: Invest Europe 2017 yearbook) and 7750 companies in the U.S. (source: NVCA 2017 yearbook) received VC.

One prominent reason for such a limited number of VC-backed companies is the fact that VC investors carefully screen investment opportunities and select for their investments only a tiny fraction of the proposals they receive: $2 \%$ according to Fried and Hisrich (1994), even lower based on Petty and Gruber (2011). While this "supply-driven" motivation for the small number of VC-backed companies has been studied at length in the literature, the demand side of the issue has received much less attention. Mason and Harrison (2001) identify three demand-side factors that can explain why so few companies obtain VC.
First, the quality of many entrepreneurial ventures that look for VC is simply not high enough to attract VC investors. Second, even ventures with good prospects may fail to secure VC if the presentation skills of their owners are not adequate to impress VC investors. Third, entrepreneurs may simply not look for VC at all.

Most of the ventures created by these latter entrepreneurs are probably of low quality, and entrepreneurs correctly anticipate that they would be unattractive to VC investors. However, there might be entrepreneurs who abstain from seeking VC in spite of the high quality of their ventures. This issue has not received adequate attention by previous studies, in spite of its potential importance. The thickness of the VC market depends on both the supply and the demand for VC (Gans and Stern, 2010; Roth, 2008). If entrepreneurs who may have a chance of obtaining VC abstain from seeking it, the VC market becomes thinner and the likelihood of an effective match between entrepreneurs and VC investors decreases (Bertoni et al., 2018).

In this paper, we contribute to filling this gap. We look at the demand for VC and argue that the costs and benefits associated with VC

\footnotetext{
We acknowledge support from the 7th EU Framework Programme VICO project on "Financing Entrepreneurial Ventures in Europe: Impact on Innovation,

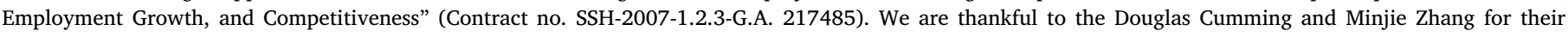
precious help in the collection of data on bankruptcy laws in European countries.

* Corresponding author at: 23 Avenue Guy de Collongue, 69134 Ecully, France.

E-mail addresses: massimo.colombo@polimi.it (M.G. Colombo), d.dadda@univpm.it (D. D’Adda), quas@em-lyon.com (A. Quas).
} 
investments, as they are anticipated by entrepreneurs, depend on the location of their ventures with respect to prospective VC investors. VC is an expensive source of funding for entrepreneurs (Brav, 2009; Bruno and Tyebjee, 1985) considering the dilution of ownership, the transfer of control rights and the direct search costs associated with establishing contacts and negotiating with VC investors. Arguably, geographic distance increases such costs and decreases the potential benefits of VC. If entrepreneurs with high-quality ventures anticipate that the costs of VC backing may outweigh its potential benefits because of geographic distance from prospective VC investors, they may not be willing to look for VC, with negative implications for the aggregate demand for VC, especially in peripheral regions.

Studying how ventures' location influences the demand for VC contributes to enlarge the scope of the literature on the "geography of VC" (Chen et al., 2010; Cumming and Dai, 2010; Lindgaard Christensen, 2007; Sorenson and Stuart, 2001). The geographical distribution of VC investments is not even; most investments are concentrated in specific areas such as Silicon Valley, the Boston and New York metropolitan areas in the U.S., and the London and Paris metropolitan areas in Europe. ${ }^{1}$ The literature has focused on the supply side of the market to explain the uneven geographical distribution of VC investments. VC investors are spatially concentrated in "VC hubs" that are located in financial centers and high-tech regions, and exhibit a strong tendency to invest nearby. ${ }^{2}$ A few studies have suggested that the uneven geographical distribution of VC investments may also be a reflection of demand-side factors, as companies in peripheral regions are less likely to seek VC (Bertoni et al., 2016, 2018; Mason and Harrison, 2002). We take a further step by investigating how geographical distance, national borders and the characteristics of prospective VC investors influence the stimulus generated by the availability of VC on ventures' demand for VC.

These issues are especially important for European ventures. The low level of VC investments in Europe compared with the U.S. and the fragmentation of the European VC market into separated national markets are considered prominent reasons for the underdevelopment of the European high-tech entrepreneurial ecosystem (European Commission, 2007). Elucidating how the location of European ventures and VC investors influences ventures' demand for VC may help to clarify the source of the European anomaly.

Accordingly, our empirical investigation is based on a sample of 533 European high-tech entrepreneurial ventures extracted from the VICO database. The VICO database includes information on young high-tech ventures located in seven European countries - Belgium, Finland, France, Germany, Italy, Spain and the United Kingdom - and is particularly appropriate for our analysis. VICO is designed to include companies that are very likely to be potential targets for VC investments. The European dimension of the VICO database offers an ideal test bed to assess the impact of national borders on ventures' demand for VC. The availability of VC differs remarkably across European countries and regions. In addition to two large VC hubs located in the London and Paris areas, several other VC hubs are heterogeneously distributed in other countries (Martin et al., 2005, for instance, show that in Germany, the VC industry is spread across six hubs). The panel dimension of the VICO database is also interesting for our purposes. Our dataset includes

\footnotetext{
${ }^{1}$ In 2016, ventures located in California, Massachusetts, and New York accounted for $75 \%$ of U.S. VC dollars invested and $52 \%$ of the total number of U.S. VC deals (source: NVCA 2017 Yearbook). As we show later, according to our data, the Inner London and Île-de-France (Paris) regions represented $21.3 \%$ and $15.7 \%$, respectively, of the new VC investments in Europe between 1984 and 2009.

${ }^{2}$ This "local bias" of VC investors is the result of both the location of their networks of informants (Cumming and Dai, 2010) and the need for spatial proximity to effectively monitor their portfolio companies (Lerner, 1995).
}

observations between 1984 and 2009, which gives us the opportunity to observe the development of the different VC markets over 25 years.

The 533 VICO companies included in our sample are the respondents of a survey that was administered in 2010. The survey asked ventures whether and when they actively looked for external equity ${ }^{3}$ in the first 15 years of their existence. We complement company-level information from the VICO database with longitudinal VC market-level data on the availability of VC across European regions and the level of competition in local VC markets. The latter information is extracted from Thomson One.

Our results show that proximity to VC hubs where there is a large availability of VC is a key driver of ventures' propensity to look for external equity, but this effect rapidly declines with geographical distance and vanishes beyond $250 \mathrm{~km}$. It also vanishes when crossing national borders. The negative effect of distance from prospective VC investors on the demand for VC varies with the characteristics of those VC investors in terms of their ownership and governance (Bertoni et al., 2015; Dimov and Gedajlovic, 2010) and reputation (Nahata, 2008; Pollock et al., 2015; Sorensen, 2007). Independent (i.e., US-style) VC investors have a strong positive effect on the demand for external equity in a radius of $250 \mathrm{~km}$, while for governmental VC investors (i.e. VC firms owned by governmental bodies), the corresponding effect is much weaker, disappearing beyond $50 \mathrm{~km}$. With respect to reputation, the stimulating effect on the demand for VC of highly reputed VC investors extends to ventures that are located abroad. In addition, we find that the level of competition (proxied by concentration) in local VC markets does not significantly influence ventures' propensity to look for external equity. Finally, we investigate the effects of cultural and institutional differences across countries on the demand for VC and find that national borders represent a lower barrier if the cultural and institutional distance between two countries is lower.

Our findings are robust to endogeneity issues due to the potential reverse causality between location and the demand for external equity, ${ }^{4}$ concerns related to the attractiveness of our sample companies for VC investors, a possible non-response bias, the Internet bubble period, the presence of multi-office VC firms and changes in the model specification.

The paper proceeds as follows. In Section 2, we build on the existing literature to develop the theoretical framework of this study. In Section 3 , we present the data used in our econometric analysis. In Section 4, we describe the econometric model. We discuss the main results and robustness checks in Sections 5 and 6, respectively. In Section 7, we provide additional evidence illustrating how the negative effects of geographical distance and national borders on the stimulus on the demand for external equity generated by the availability of VC depend on the characteristics of VC investors and cultural and institutional difference between countries. In Section 8, which concludes the paper, we summarize our main results and discuss the study's contribution to the VC literature, the study's limitations, directions for future research, and the study's managerial and policy implications.

\footnotetext{
${ }^{3}$ The survey did not directly inquire about ventures' search for VC but rather about "equity that is provided by sources other than founders, their family members and friends". Therefore, our study investigates whether the location of European ventures and that of prospective VC investors influence ventures' demand for external equity from whatever source. In our theorizing, we assume that ventures' demand for external equity and for VC are closely related.

${ }^{4}$ In the main analysis, we assume that entrepreneurs are unlikely to choose the location of their business according to the availability of VC in a given area. This assumption is well supported by existing literature (Audretsch and Stephan, 1996; Bertoni et al., 2018; Michelacci and Silva, 2007; Zucker et al., 1998). Nevertheless, in the empirical section, we present robustness checks that mitigate concerns about potential reverse causality between the location of sample ventures and their demand for VC.
} 


\section{Theoretical framework: how location influences the demand for venture capital}

\subsection{The expected costs and benefits of accessing VC and the demand for VC}

The benefits of VC are well documented. First, the injection of financial resources reduces financial constraints in entrepreneurial ventures (Carpenter and Petersen, 2002). Second, the "coaching" of entrepreneurial teams by VC investors and the network of contacts they bring to their portfolio companies enhance their value (Gorman and Sahlman, 1989; Sapienza, 1992).

Despite these benefits, only a minority of firms seek external equity (and VC) to finance their businesses (Ou and Haynes, 2006; Vos et al., 2007). In Cosh et al.'s (2009) study of UK entrepreneurial ventures, out of the 2520 sample companies, 952 sought external finance during the observation period, but only 87 attempted to approach a venture capitalist. Under some conditions, entrepreneurial ventures may prefer alternative sources of finance, such as public subsidies or crowdfunding, and may even choose to adapt their business models to a less capital-intensive setting so that they can operate without VC. ${ }^{5}$

Indeed, companies will not look for VC if expected benefits do not compensate for expected costs. The first and most obvious cost that entrepreneurs incur while obtaining VC is the dilution of their ownership stakes. Dilution is amplified by information asymmetries, as VC investors facing such asymmetries ask for a "lemon" premium (Akerlof, 1970) to compensate for their extra risk and thus offer lower pre-money valuations (Brav, 2009).

Subtler costs associated with VC arise from the potential loss of control. VC contracts typically include performance-contingent clauses that partition control rights between existing and outside investors (Kaplan and Strömberg, 2003). These clauses limit entrepreneurs' decision autonomy, especially when their venture's performance is poor (Burchardt et al., 2016). The risk of losing control of the company discourages entrepreneurs from seeking VC. In accordance with this argument, Brav (2009) shows that UK private firms with less dispersed ownership, i.e., those with a stronger desire to retain control, are less likely to rely on external equity financing and have higher debt ratios.

Finally, new ventures must face additional (opportunity or real) costs merely to have access to the VC market. Considerable money and time are required to write an appealing business plan, to search for and meet prospective investors, to prepare an elevator pitch, to carry out due diligence, to protect intellectual property and finally, to negotiate and conclude a deal (Carpentier and Suret, 2006). Bruno (1985) estimates that the median time that ventures spend searching for funds is four to five months, but for $20 \%$ of their U.S.-based sample, it was more than eight months.

Below, we argue that the location of new ventures with respect to prospective VC investors influences the balance between the anticipated costs and the anticipated benefits of obtaining VC, thereby making ventures either more or less inclined to seek VC.

\subsection{Geographical distance from prospective $V C$ investors and the demand for $V C$}

Despite advances in information and communication technologies and physical infrastructures (most notably low-cost flights and highspeed trains), the geographical distance between ventures and prospective VC investors is likely to reduce the benefits and increase the

\footnotetext{
${ }^{5}$ The drawbacks of VC and the careful analysis that is required to evaluate the benefits and costs of having VC investors on board are often mentioned in the business press. See, e.g., https://www.valuewalk.com/2018/06/avoid-venturecapital-straight-talk-for-startups/ and https://www.forbes.com/sites/ davidkwilliams/2017/04/17/the-case-for-avoiding-venture-capital/\# eb567d73c788.
}

costs entrepreneurs anticipate will be incurred by obtaining VC, negatively influencing their propensity to seek VC.

Even if the World Wide Web in principle allows entrepreneurs to find information on VC investors located all over the world and contact them with little difficulty, in practice this rarely happens. First, entrepreneurial ventures located far from VC hubs tend to be less aware of the benefits of VC and less likely to look for it. Indeed, the word-ofmouth effect generated by other local VC-backed ventures is still a fundamental driver of the demand for VC. As Martin et al. (2005) argue, "Experience and knowledge of the local VC market spread through the local business and information networks to encourage additional entrepreneurial activity to seek private equity" (p. 1214).

Second, even if entrepreneurial ventures are aware of the benefits of VC, they probably know that VC investors typically rely on their local information networks to screen business proposals (Cumming and Dai, 2010; Sorenson and Stuart, 2001) and seldom invest without a referral from a trusted informant (Fiet, 1995). Hence, entrepreneurs have to rely on their social capital to get in contact with prospective VC investors (Shane and Cable, 2002). However, entrepreneurs' social networks also tend to be geographically concentrated around their premises (Stuart and Sorenson, 2003) and therefore may hardly include prospective VC investors located far away. For such VC investors, geographical distance amplifies information asymmetries and creates greater uncertainty because of the unfamiliarity with the context in which the focal venture is embedded. Faced with greater information asymmetries and uncertainty, VC investors may demand a higher "lemon" premium to invest at a long distance, increasing the anticipated costs of obtaining VC for distant ventures (Carpentier and Suret, 2006).

Geographical distance matters also in the post-investment period. Proximity allows for more frequent meetings between VC investors and their portfolio companies, and therefore for more effective coaching and monitoring. Better coaching boosts the expected benefits of VC, while more effective monitoring reduces expected agency costs (Cumming and Dai, 2010). The negative effects of geographical distance on effective coaching and monitoring are attenuated but not eliminated by advances in transportation, which have progressively reduced the costs of face-to-face meetings between entrepreneurs and distant VC investors (e.g., Bernstein et al., 2016).

In sum, we expect that geographical distance from prospective VC investors has a negative influence on a focal venture's demand for VC because it increases the expected costs of VC and decreases its expected benefits. It is a crucial empirical issue to quantify this effect and investigate the distance from prospective VC investors at which the stimulus on the demand for VC disappears. Moreover, the distance decay of the stimulus likely depends on the characteristics of VC investors. In this study, we consider two characteristics that have attracted the attention of VC scholars: the ownership and governance of VC investors (Bertoni et al., 2015; Dimov and Gedajlovic, 2010), distinguishing private and public (i.e., government-owned) VC investors, and their reputations (Nahata, 2008; Pollock et al., 2015; Sorensen, 2007). Previous studies show that the positive impact on portfolio companies of governmental VC investments is more limited than the impact of private VC investments (e.g., Alperovych et al., 2015; Bertoni and Tykvová, 2015; Brander et al., 2015; Cumming et al., 2017; Grilli and Murtinu, 2014). Moreover, the impact of VC investments is higher if the investors are more reputed (Nahata, 2008; Sorensen, 2007). Therefore, entrepreneurs may anticipate smaller benefits from obtaining VC from governmental VC investors and larger benefits from obtaining it from more reputed VC investors. ${ }^{6}$ Accordingly, the negative effect of distance from prospective VC investors on the stimulus on the demand for VC

\footnotetext{
${ }^{6}$ The larger benefits entrepreneurs anticipate from obtaining VC from more reputed investors are indirectly witnessed by the premium they pay for this type of investment, which Hsu (2004) estimates to be as large as 14\%.
} 
should be weaker from more reputed investors. The opposite should hold for governmental VC investors (i.e., we expect a weaker stimulus that vanishes more rapidly with greater geographical distance).

\subsection{Cross-border availability of VC and the demand for VC}

Entrepreneurs may go beyond national borders in their search for VC. Cross-border VC inflows may compensate for potential limits in the domestic VC supply (Schertler and Tykvova, 2012). Moreover, crossborder VC has potential benefits for entrepreneurial ventures over and above those that they can obtain from domestic VC. Foreign VC investors may help entrepreneurial ventures expand their business into the country of the investor (Mäkelä and Maula, 2005) or exploit the exit opportunities there, if local exit conditions are inadequate (Bertoni and Groh, 2014). Thus, one might expect entrepreneurs to be especially inclined to look for VC if their ventures are located in proximity to foreign VC hubs, where there is an abundant availability of VC.

However, other factors could make access to foreign VC extremely costly for entrepreneurs. First, entrepreneurs and prospective VC investors located in different countries are set apart by linguistic and cultural distance, which implies differences in values, beliefs and practices. These differences increase the information asymmetries and perceived investment risks for VC investors, resulting in greater anticipated costs for entrepreneurs in terms of ownership dilution and loss of control rights. They are also likely to make coordination between entrepreneurs and VC investors more difficult, which in turn makes VC investors' coaching and monitoring less effective, reduces the expected benefits and increase the expected agency costs of VC investments (Dai et al., 2012; Li et al., 2014; Nahata et al., 2015).

Second, cross-country differences in regulations and tax policies increase the complexity and the costs of due diligence on the part of VC investors (Cumming and Macintosh, 2003; Wright et al., 2005). This is particularly true in Europe, especially before the introduction of the European VC passport in 2013 (European Parliament, 2013). As noted by the European Commission, "in a fragmented venture capital market with currently 27 different operating environments, fund structuring across multiple borders becomes increasingly complex and smaller funds tend to avoid operating outside their home jurisdictions" (European Commission, 2007). As a result, entrepreneurs will again anticipate higher costs of obtaining VC from foreign VC investors.

In sum, whether the expected benefits of cross-border VC investments exceed the expected costs is an interesting empirical question that can be approached by looking at the impact of the availability of VC beyond national borders on ventures' propensity to look for VC. Moreover, the cultural and institutional distance between the countries in which entrepreneurs and prospective VC investors are located is likely to negatively moderate this relationship.

\subsection{Competition in the VC market and demand for VC}

Ventures' location may also influence the terms that VC investors offer them. Gompers and Lerner (2000) find important geographical differences in the pre-money valuations that VC investors offer their target companies. They suggest that in regions with high competition among VC investors for a limited number of attractive targets, VC investors offer higher valuations to entrepreneurs.

More generally, the more competitive the local VC market, the better the conditions that VC investors must offer to local entrepreneurs to secure promising investment opportunities. If local entrepreneurs anticipate inferior dilution costs and a lower loss of control rights, they will be more willing to look for VC. Therefore, we expect that the level of competition in the local VC market has a positive influence on the VC-seeking propensity of entrepreneurial ventures located in the same region.

\section{Data}

\subsection{Sample}

We test our predictions on a panel dataset composed of 533 European high-tech entrepreneurial ventures that were potential or actual targets of VC investments and responded to an online survey we administered in 2010. The sample companies were extracted from the VICO database, ${ }^{7}$ which includes detailed information for a large sample of high-tech entrepreneurial ventures operating in seven European countries: Belgium, Finland, France, Germany, Italy, Spain and the United Kingdom. All ventures included in the sample were founded after 1984, were independent at their foundation (i.e., they were not controlled by other business organizations), and operate in the following high-tech manufacturing and service industries: nanotechnology; biotechnology; pharmaceuticals; computers; electronic components; telecommunications equipment; precision, optical and medical instruments; robotics; aerospace; software; telecommunications services; Internet and multimedia services; web publishing; renewable energies; R\&D and engineering services.

The VICO database includes two strata of ventures: 759 VC-backed ventures and 7611 non-VC-backed ventures that are "potential targets of VC investments" (Bertoni and Martí, 2011). VC-backed companies received the first VC round from 1994 to 2004 when they were no more than 10 years old. They were randomly extracted from commercial databases (i.e., Thomson One, VC-PRO, and Zephyr) and country-specific proprietary databases, including the yearbooks of the Belgium Venture Capital Association and the Finnish Venture Capital Association, the ZEW Foundation Panel (Germany), the Research on Entrepreneurship in Advanced Technologies (RITA) directory and Private Equity Monitor (Italy), the Webriesgo Database (Spain), and the Library House (now called Venture Source; the UK). Moreover, data on VC-backed companies and their investors were cross-checked by a central data processing unit with those available from public sources (e.g., websites and annual reports of VC investors, press releases and press clippings, and initial public offering prospectuses). Therefore, data in the VICO database are more reliable than those available in commercial databases. The non-VC-backed firms were included in the VICO database following the same criteria relating to country, age, independence, industry, and legal status used for the inclusion of the VC-backed firms, and they were randomly extracted (conditional on these criteria) from all available years of Bureau van Dijk's Amadeus database. We resorted to additional information sources to improve the coverage of the dataset and assure data reliability (i.e., industry associations and Chamber of Commerce directories, commercial firm directories, Zephyr, Creditreform, the ZEW Foundation Panel, and the RITA directory). Ventures in the VICO database are observed from their foundation date to 2010 (or the time at which they ceased operations or were acquired).

In February 2010, we sent an online survey to the 5417 VICO companies for which we had a valid email address, to collect information about their demand for external equity. Respondents answered "Yes" or "No" to the question "Has your company ever sought equity financing from sources other than founders, their family members and friends?". To companies that answered "Yes", we also asked when they actually sought financing. The possible non-exclusive answers were "before or at the time of foundation; in the first 2 years after foundation; between the 2nd and 5th years after foundation; between the 5th

\footnotetext{
${ }^{7}$ The VICO dataset was built through the joint effort of nine universities across Europe with the support of the 7th European Framework Program. For more details on the procedures used in the data-gathering process and on all the variables included in the database, see Bertoni and Martí (2011).
} 
Table 1

Number of sample ventures seeking external equity: break down by industry, country, foundation year.

\begin{tabular}{|c|c|c|c|c|c|c|c|c|c|}
\hline & \multicolumn{3}{|c|}{ Not seeking ext. equity } & \multicolumn{3}{|c|}{ Seeking ext. equity } & \multicolumn{3}{|c|}{ Total } \\
\hline & No. & $\mathrm{Col} \%$ & Row \% & No. & $\mathrm{Col} \%$ & Row \% & No. & $\mathrm{Col} \%$ & Row \% \\
\hline \multicolumn{10}{|c|}{ Industry $($ Pearson chi2(5) $=9.1216 \operatorname{Pr}=0.104)$} \\
\hline Biotech, Pharma, Other R\&D & 48 & 17.02 & 44.44 & 60 & 23.90 & 55.56 & 108 & 20.26 & 100.00 \\
\hline ICT manufacturing & 60 & 21.28 & 55.56 & 48 & 19.12 & 44.44 & 108 & 20.26 & 100.00 \\
\hline Internet \&Multimedia & 17 & 6.03 & 56.67 & 13 & 5.18 & 43.33 & 30 & 5.63 & 100.00 \\
\hline Other manufacturing & 24 & 8.51 & 68.57 & 11 & 4.38 & 31.43 & 35 & 6.57 & 100.00 \\
\hline Software & 126 & 44.68 & 54.08 & 107 & 42.63 & 45.92 & 233 & 43.71 & 100.00 \\
\hline Telecommunications & 7 & 2.48 & 36.84 & 12 & 4.78 & 63.16 & 19 & 3.56 & 100.00 \\
\hline Total & 282 & 100.00 & 52.91 & 251 & 100.00 & 47.09 & 533 & 100.00 & 100.00 \\
\hline \multicolumn{10}{|c|}{ Country $($ Pearson chi2 $(6)=22.7888, \operatorname{Pr}=0.001)$} \\
\hline Belgium & 20 & 7.09 & 38.46 & 32 & 12.75 & 61.54 & 52 & 9.76 & 100.00 \\
\hline Finland & 38 & 13.48 & 51.35 & 36 & 14.34 & 48.65 & 74 & 13.88 & 100.00 \\
\hline France & 38 & 13.48 & 43.68 & 49 & 19.52 & 56.32 & 87 & 16.32 & 100.00 \\
\hline Germany & 17 & 6.03 & 56.67 & 13 & 5.18 & 43.33 & 30 & 5.63 & 100.00 \\
\hline Italy & 66 & 23.40 & 68.04 & 31 & 12.35 & 31.96 & 97 & 18.20 & 100.00 \\
\hline Spain & 74 & 26.24 & 60.16 & 49 & 19.52 & 39.84 & 123 & 23.08 & 100.00 \\
\hline United Kingdom & 29 & 10.28 & 41.43 & 41 & 16.33 & 58.57 & 70 & 13.13 & 100.00 \\
\hline Total & 282 & 100.00 & 52.91 & 251 & 100.00 & 47.09 & 533 & 100.00 & 100.00 \\
\hline \multicolumn{10}{|c|}{ Foundation year classes (Pearson chi2 $(4)=11.7718, \operatorname{Pr}=0.019)$} \\
\hline $1984-1988$ & 38 & 13.48 & 66.67 & 19 & 7.57 & 33.33 & 57 & 10.69 & 100.00 \\
\hline 1989-1992 & 39 & 13.83 & 65.00 & 21 & 8.37 & 35.00 & 60 & 11.26 & 100.00 \\
\hline $1993-1996$ & 42 & 14.89 & 50.00 & 42 & 16.73 & 50.00 & 84 & 15.76 & 100.00 \\
\hline 1997-2000 & 80 & 28.37 & 45.71 & 95 & 37.85 & 54.29 & 175 & 32.83 & 100.00 \\
\hline 2001-2004 & 83 & 29.43 & 52.87 & 74 & 29.48 & 47.13 & 157 & 29.46 & 100.00 \\
\hline Total & 282 & 100.00 & 52.91 & 251 & 100.00 & 47.09 & 533 & 100.00 & 100.00 \\
\hline
\end{tabular}

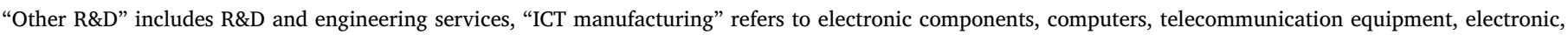
medical and optical instruments while "Other manufacturing" includes aerospace, robotics and automation equipment.

and 10th years after foundation; after the 10th year after foundation". 8 We sent four reminders between February and April 2010. To fill in missing data and check the reliability of the information provided by sample ventures, we complemented the online survey with several phone interviews. Ultimately, we received 814 answers (response rate of $15.03 \%)$.

In this paper, we use the data on the 533 ventures for which we have complete information with regards to the variables of interest. We populate an unbalanced panel dataset in which we track yearly information on these companies in the first 15 years of their lives. We exclude companies that are older than 15 years, as VC financing is typically used in the early stages of entrepreneurial ventures' life. The oldest company was born in 1984 and the youngest in 2004. The dataset covers the period from 1984 to 2009, one year before our survey was carried out.

\subsection{Sample descriptive statistics}

Out of the 533 high-tech entrepreneurial ventures in our sample, $251(47.1 \%)$ had actively sought external equity financing at some point. Table 1 distinguishes the sample ventures based on whether they had ever sought external equity financing, and for each category of ventures, it provides a breakdown by industry, country and foundation year. The $\chi^{2}$ tests shown in the table highlight significant differences between external equity seeking and non-seeking ventures by country and foundation year classes and nearly significant differences by

\footnotetext{
${ }^{8}$ To reduce retrospective bias and increase response rates, we decided not to inquire about ventures' seeking behavior on a year-by-year basis. That option would have meant administering a much longer survey questionnaire with a much higher level of detail, and it would have probably led to less complete and reliable answers from a lower number of respondents.
}

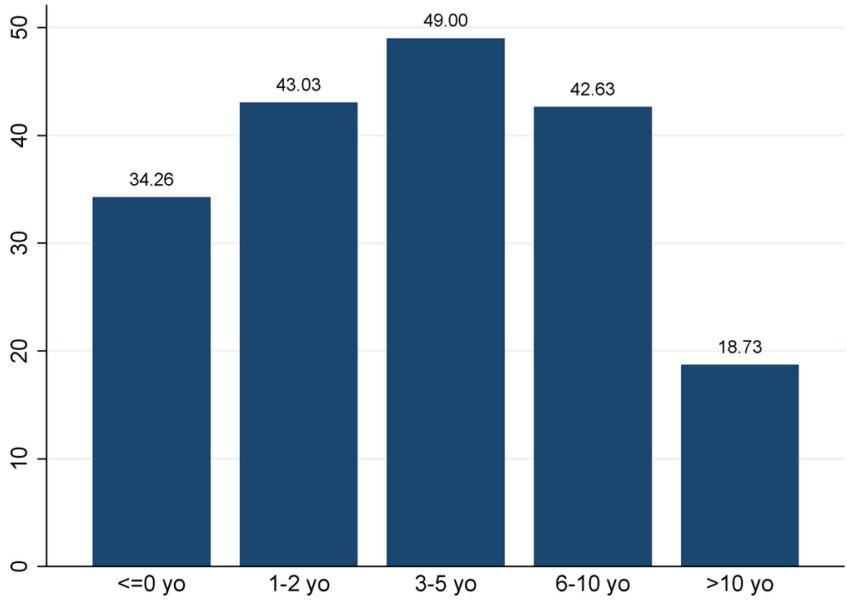

Fig. 1. Percentage of sample ventures seeking external equity by age class.

industry. Ventures located in Belgium, the United Kingdom and France are more likely to look for external equity, while ventures in Italy and Spain are less inclined to do so. Younger ventures (especially those founded between 1997 and 2000) exhibit a higher propensity to seek external equity. Finally, ventures in biotech, pharmaceuticals and other R\&D services are more likely to look for external equity than ventures in other industries.

In Fig. 1, we show the age at which sample companies looked for external equity. To build the figure, we excluded VC-backed companies after receipt of the first VC round, as we are not interested in companies looking for additional rounds of financing. Therefore, for each age class, the figure shows the number of non-VC-backed companies that looked for external equity divided by the number of companies that completed 
the survey and in that age class, had not yet received VC. The ventures may have looked for external equity at more than one period in their lives. Their propensity to look for external equity peaks in the period between the 3rd and the 5th year after founding. Conversely, few ventures did so after the 10th year.

\subsection{The geographical distribution of VC investments in Europe}

We retrieved information about the geographical distribution of VC investments in Europe from the Thomson One database. On 26 February 2016, we downloaded the full list of VC investments carried out between 1984 and 2009 by European VC investors (39083 investments in total). Of these investments, we focused on new investments, i.e., investments in which an investor financed a company for the first time. As we will explain below, we will use these data to measure the availability of VC. We assigned each new investment to a geographical region based on the location of the VC investor ${ }^{9}$. We used the NUTS2 (Nomenclature of Territorial Units for Statistics) 2010 classification to identify geographical regions. ${ }^{10}$ The European Union's territory is subdivided into 270 NUTS2 regions. On average, a NUTS2 region has an area of $16310 \mathrm{~km}^{2}$, equivalent to a spherical radius of $40.67 \mathrm{~km}$ (Eurostat, 2011). To assign each VC investor to a NUTS2 region, we first translated the textual information on the ZIP code, city and country of the VC headquarters (provided by Thomson One) into numerical information on the latitude and longitude coordinates. This geocoding process was automated using Google Maps Geocoding API and the R command "geocode". We then used geographical data on the administrative boundaries of each NUTS2 (retrieved from Eurostat's website) to link each pair of VC coordinates with a NUTS2 identifier.

Fig. 2 shows the number of new investments by the location of VC investors (at the NUTS2 level) over the 1984-2009 period. The Inner London and Île-de-France (Paris) regions stand out; they represent $21.3 \%$ and $15.7 \%$, respectively, of new investments. The analysis of the location of the invested companies and their VC investors shows a strong co-location tendency. During the period analysed, $78.1 \%$ of invested companies received VC from investors located in the same country as the invested company. In $35.2 \%$ of cases, they were located in the same NUTS2 region.

\section{Econometric model}

\subsection{Dependent variable}

In this section, we describe the econometric model used to test our predictions regarding ventures' demand for external equity. Our dependent variable measures whether the sample entrepreneurial ventures looked for external equity in a particular calendar year. To build this variable, we used the answers that our 533 sample companies gave to the survey questions on whether and when they had ever sought equity finance from sources other than founders, their family members and their friends. We constructed a time-varying variable, VCseeking ${ }_{i, t}$,

\footnotetext{
${ }^{9}$ Please note that a single round of investment can be counted more than once according to the number of syndicating investors. We considered all new investments made by European VC investors independently of the location of portfolio companies (i.e., they may be located in Europe or elsewhere).

${ }^{10}$ The NUTS classification is a single, coherent system for dividing the European Union's territory created by the European Commission to produce regional statistics. The NUTS classification is based on three hierarchical levels: NUTS1 (major socio-economic regions), NUTS2 (basic regions used by the European Commission for the application of regional policies) and NUTS3 (small regions for specific diagnoses). Eurostat set up the NUTS classification at the beginning of the 1970s and updated it several times since then according to changes in the regional breakdown of countries. In this paper, we use the NUTS 2010 classification introduced on 7 February 2011 (Commission Regulation (EU) No 31/2011) at the NUTS2 level.
}

which takes a value of 1 in all calendar years $t$ included in a period in which company $i$ looked for external equity and 0 otherwise. The variable was defined from one year before foundation to the 15th year after foundation. As we mentioned earlier, for VC-backed companies, we excluded from the sample all years after the receipt of the first VC round. Our observation period goes from 1984 (the foundation year of our oldest sample company) to 2009 (one year before the survey was administered). In Fig. 3a, we plot the yearly percentage of sample firms seeking external equity (equal to the mean of the dummy VCseeking ${ }_{i, t}$ by year). For comparison purposes, in Fig. $3 \mathrm{~b}$ we plot the total number of new investments made by European VC investors between 1984 and 2009 according to Thomson One. The percentage of companies seeking external equity peaks in 2000 , a finding that is consistent with the large number of investments around the bubble period. This first evidence suggests that the demand for external equity has sensitively changed over time and is correlated to the yearly number of investments by VC investors.

\subsection{Independent variables: the weighted distance and the radius specifications}

Our independent variables assess the effect of the geographical distance between the locations of companies and prospective VC investors on companies' demand for external equity. To develop these variables, we use information from two sources. From Thomson One, we retrieved data on the number of new investments by European VC investors and their location. From VICO, we use information about the location of sample companies. We use two alternative specifications in which we model differently the impact of the distance from the location of prospective VC investors: the "weighted distance" specification and the "radius" specification.

In the "weighted distance" specification, we include three variables capturing the availability of VC in the same region of the company, in the same country and abroad: VCavailability_local ${ }_{i, t}$, $V_{\text {Cavailability_national }}$, and VCavailability_abroad ${ }_{i, t}$. The variable $V_{\text {Cavailability_local }}$, is the number of new investments made in the previous 3 years $(t-3, t-2$ and $t-1)$ by VC investors with headquarters in the same NUTS2 region as the focal company, in logarithm. ${ }^{11}$ The variables VCavailability_national ${ }_{i, t}$ and VCavailability_abroad ${ }_{i, t}$, are distance-weighted indexes of the availability of VC outside the region but in the same country and outside the country in which the focal company is located, respectively. To build these variables, instead of considering the VC availability in all 270 NUTS2 regions in Europe, we consider only the regions that ranked among the top 50 in terms of the number of VC investments in a 3-year window. We call these 50 regions "VC hubs". ${ }^{12}$ Investments in these 50 hubs represent $87.2 \%$ of the total number of investments in Thomson One. We consider only the $50 \mathrm{VC}$ hubs to lower the computation burden, assuming that if a focal region is the site of limited VC activity, it is unlikely that the number of VC investments in the region has any stimulating effect on the demand for external equity of companies located outside the region. Our measures of the distance-weighted availability of VC are equal to the weighted average of the VC availability in each VC hub except the one in which the focal company is located. We use the distance between the hub and the focal company as the weight. Specifically, the variables are defined

\footnotetext{
${ }^{11}$ We use a 3 year window to stabilize the variable over time. As robustness checks, we performed similar analyses using, alternatively, the new investments made in the past 5 years or in the past year only. We also repeated the analysis considering, instead of new investments, all investment rounds and first investment rounds only. In all cases, we obtained similar results, which are available from the authors upon request.

${ }^{12}$ In the period under examination, the NUTS2 regions that are defined as "VC hubs" are remarkably stable. This is especially true in the past decade: 30 regions are defined as VC hubs over the entire period and the other 20 are defined as VC hubs over at least 6 years.
} 


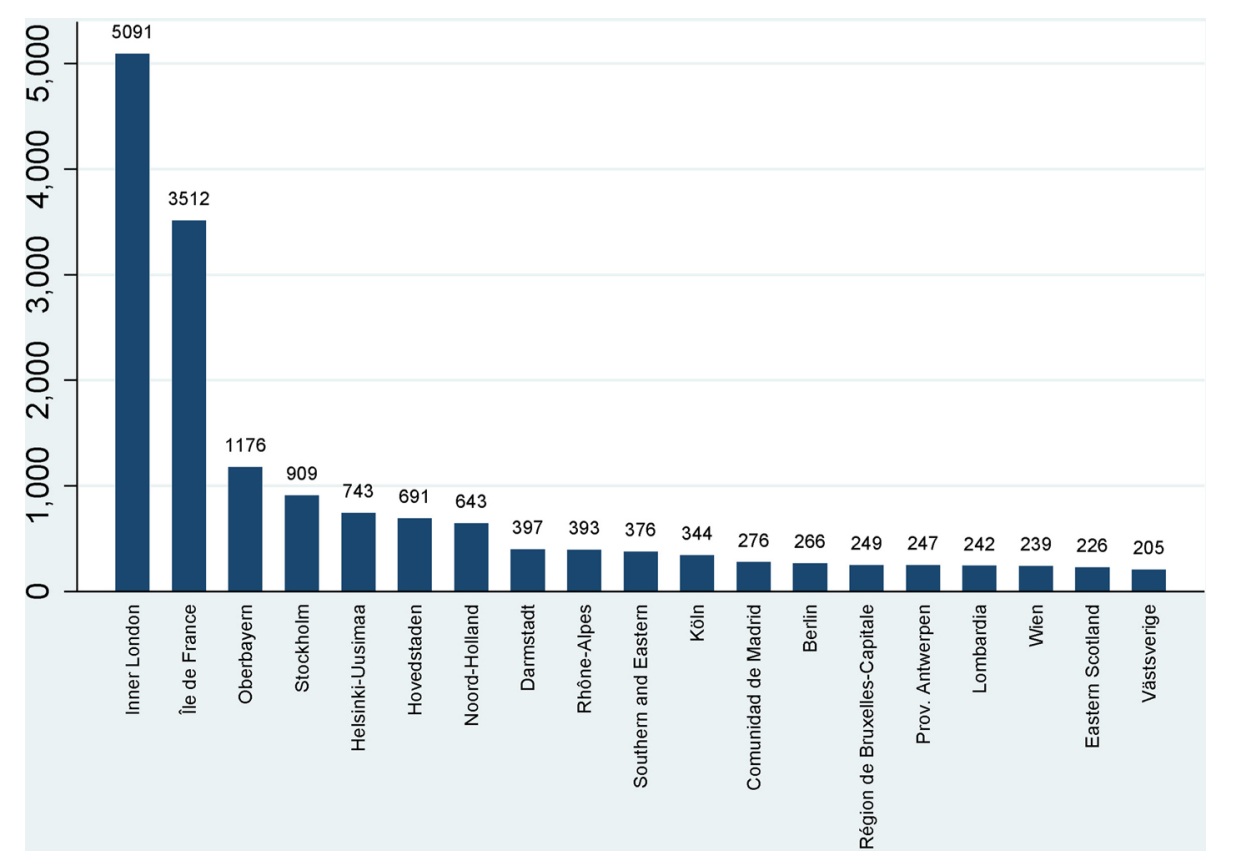

Fig. 2. Total number of new investments by VC investors' location (1984-2009). Source: own elaboration based on Thomson One data. Please note that each VC investment is counted more than once when it is syndicated, i.e. an investment made by $3 \mathrm{VC}$ investors is counted as one for each NUTS2 region where the investors are located.

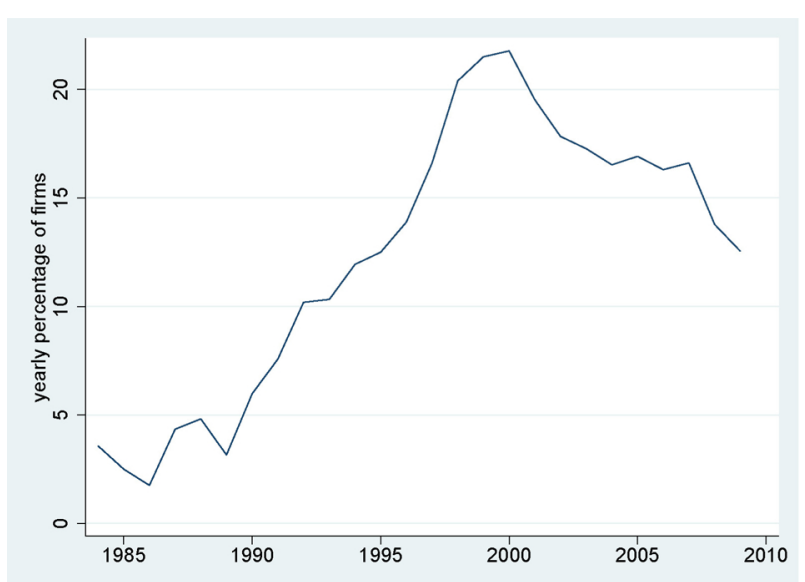

(a) percentage of sample ventures seeking external equity

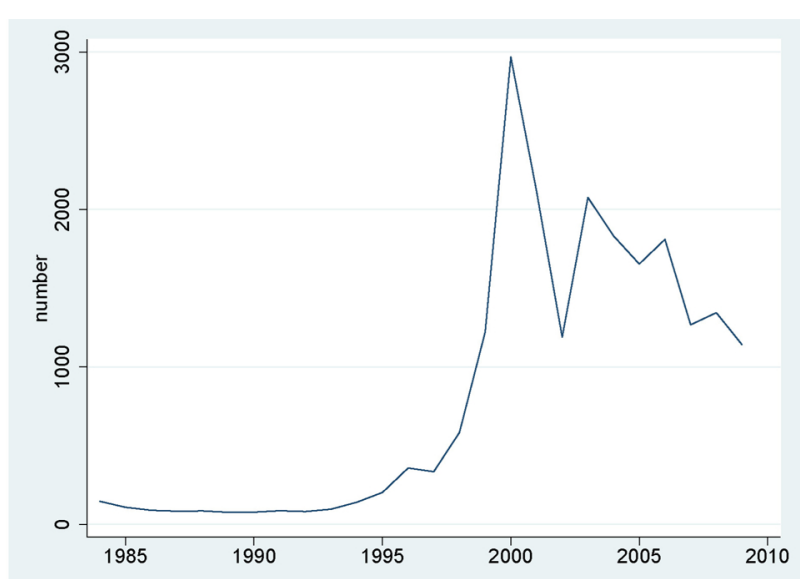

(b) new investments made by European VC investors

Fig. 3. Number of new investments made by European VC investors and percentage of sample ventures seeking external equity by year.

as follows:

VCavailability_n ational $_{i, t}=\log \sum_{l \in C_{i, t}, l \neq k_{i}} \frac{\text { VCavailability_l ocal }_{l, t}}{\text { distance }_{i, l, t}{ }^{\alpha 1}}$

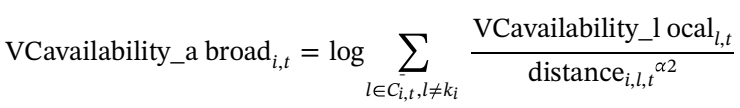

where $C_{i, t}$ is the group of VC hubs within the country in which company $i$ is located (excluding the region in which the company is located $-k_{i}$, if it is a hub) and $\bar{C}_{i, t}$ is the group of cross-border VC hubs $\left(C_{i, t} \cup \bar{C}_{i, t}=50\right.$ VChubs). $l$ denotes each of those hubs, VCavail${\text { ability } \text { local }_{l, t} \text { is the local availability in hub } l \text { and distance }}_{i, l, t}$ is the distance (in $10 \mathrm{~km}$ ) between the centroid of hub $l$ and the location of company $i{ }^{13} \alpha 1$ and $\alpha 2$ are the decay factors for distance. We set $\alpha 1$ and $\alpha 2$ to the values that maximize the log-likelihood function of our

\footnotetext{
${ }^{13}$ We identify the centroid of a hub as the average of the positions of the VC investors located in the region, using the number of investments as weight.
}

econometric model (for a similar approach, see Bonaccorsi et al., 2014). A detailed description of the procedure that we used to estimate the decay parameters values is given in Appendix A. According to this procedure, the optimal decay parameter values are 1 for VCavailability_national $_{i, t}(\alpha 1)$ and 0.3 for VCavailability_abroad $d_{i, t}(\alpha 2)$. Calibrated parameters higher than 0 suggest that the greater the distance of a company's location from a VC hub, the lower the allegedly positive effect of the availability of VC in the hub on the company's demand for VC. The fact that $\alpha 1$ is higher than $\alpha 2$ indicates that distance discourages the demand for VC more within than across national borders.

The second model specification that we use is the "radius" specification. In this model, we use different independent variables to account for the geographic distribution of VC, each capturing the availability of VC within a certain radius of distance within and beyond national borders. The variable VCavailability_national_ $d_{0_{-}} d_{1-} k m_{i, t}$, is the log of the number of new investments over the previous three years made by VC investors located in regions whose centroid is at a distance between $d_{0}$ and $d_{1}$ kilometres from the focal company and in the same country as the focal company. Similarly, VCavailability_abroad_d $d_{0_{-}} d_{1 \_} k m_{i, t}$ is the log of the number of new investments over the previous three years made 
by VC investors located in regions whose centroid is at a distance between $d_{0}$ and $d_{1}$ kilometres from the focal company and in a different country. We used $0,50,250,500,1000$ and $5000 \mathrm{~km}$ as thresholds to balance the need for a sufficiently fine-grained measure of distance and the risk of collinearity between those variables. The choice of these thresholds is also based on the estimates of the weighted distance specification, as we will show below.

In all specifications, we include our inverse proxy of the level of competition, VCconcentration_local ${ }_{i, t}$ measuring the percentage of new investments made by the top four investors in the home region of company $i$ in the last 3 years (i.e., the $\mathrm{C} 4$ concentration index).

Finally, we consider an additional model specification that builds on the results of the previous two models. We use the radius specification in which we drop variables related to distances greater than $500 \mathrm{~km}$ and we model the availability of VC beyond national borders with a single variable (VCavailability_abroad_0_500_km) that measures the crossborder availability of $\mathrm{VC}$ at a distance between 0 and $500 \mathrm{~km}$. Indeed, as we will show below, our results suggest that the availability of VC within national borders at distance greater than $500 \mathrm{~km}$ has a negligible influence on the demand for external equity, and the influence of distance is much weaker across borders than within borders. We also drop VCconcentration_local ${ }_{i, t}$ which is never significant in our models. The resulting "compact specification" is used to provide additional evidence about the moderators of the relationship between the demand for external equity and the geography of the availability of VC.

\subsection{Controls}

The econometric model includes a set of industry, country and year dummies and a continuous variable measuring the age of the focal company in logarithms $\left(a g e_{i, t}\right)$. For a subset of companies, we also have information about the human capital of the founding team, cash generation, leverage, capital expenditures and number of patents. Previous literature has identified all these variables as important drivers of companies' tendency to seek external finance (Cosh et al., 2009; Eckhardt et al., 2006; Mina et al., 2013). These variables are used here as controls. In the 2010 survey, we asked our sample companies about the human capital of their founders. In particular, we asked whether "among the founders of the company there were individuals who, before the foundation of the company: i) had previous managerial experience, ii) had founded one or more firms, iii) had obtained an MBA or a master degree in Management or Economics and iv) had obtained a PhD in technical or scientific disciplines". We coded the answers to these questions with the dummy variables manager ${ }_{i}$ serial $_{i}, M B A_{i}$ and $P h D_{s}$ science $_{i}$, respectively. We measured cash generation and leverage with the variables cashflow/ sales $_{i, t-1}$, equal to the ratio between cash flow and sales, and debt/totalassets $_{i, t-1}$, equal to the ratio between total debt and total assets. We measured capital expenditures with CAPEX/assets $s_{i, t-1}$, i.e., the variation of fixed assets with respect to the previous year divided by companies' profits. The accounting data used to compute these ratios were retrieved from Bureau Van Dijk's Amadeus dataset. The accounting variables were winsorized at the $1 \%$ level to reduce the influence of outliers. As accounting variables are unavailable for a fraction of sample companies, we impute the missing values to 0 , and generate a dummy variable called d_accounting_missing ${ }_{i, t}$ equal to 1 if the data has been imputed, and to 0 otherwise. This variable is meant to capture any change in slope of the accounting variables that the arbitrary imputation of the 0 would otherwise generate (for a similar approach, see Dale and Krueger, 2002). As a proxy for companies' innovativeness, we used the variable patents_stock $k_{i, t-1}$, which is equal to the cumulative number of patents granted to each company, depreciated over time. Granted patents were assigned to the application year, with a 0.15 knowledge depreciation rate, as is usual in the patent literature (see, e.g., Hall et al., 2005).

We also control for local conditions via additional variables measured at the NUTS2 level in each year: the logarithm of the GDP
(GDP_local $l_{i, t-1}$ ), the logarithm of the number of patents granted proxying local innovativeness (patents_local $l_{i, t-1}$ ), the size of the region measured in squared kilometres (area_local ${ }_{i}$ ) and the average ratio of debt to equity of young high-tech companies measuring the local availability of alternative sources of finance (debt_local $\left.{ }_{i, t-1}\right)$. The former three variables were retrieved from Eurostat, while the latter was extracted from the VICO database and computed as the average ratio of debt on equity of all VICO companies located in a given region.

Finally, variables at the national level are included. MSCInnational $_{i, t-1}$ is the Morgan Stanley Capital International (MSCI) index lagged by 1 year, i.e., it is a measure of stock market performance in each European country. Cumming et al. (2010) find that MSCI returns accelerate the VC due diligence process, which may stimulate companies' demand for external equity. Furthermore, Armour and Cumming $(2008,2006)$ show that bankruptcy laws influence the extent to which entrepreneurs take risk, which is likely to also affect the demand for external equity. Therefore, we include the dummy variable bankruptcylaws_national $l_{c, t-1}$, which is equal to 1 in country-years during which a bankrupt individual can obtain a "fresh start", indicating that bankruptcy law is relatively lenient. Armour and Cumming (2008) provide this information for the period 1984-2005. We completed the time series till 2009 using information retrieved from the International Insolvency Institute (https://www.iiiglobal.org/). Finally, the variable infrastructure_national $c_{c, t-1}$ measures the number of $\mathrm{km}$ of railways divided by the population in each country-year (source: Eurostat). Such variable accounts for the development of the transport infrastructures, which may reduce the costs that entrepreneurs incur in seeking external equity.

A description of all the variables used in our analysis is provided in Table 2, while Table 3 shows summary statistics and the correlation matrix. Henceforth, for sake of simplicity, we omit the indexes $i$ and $t$ that we used to better explain our variables. However, the reader should note that in all models, all variables were lagged 1 year to reduce concerns about endogeneity.

\section{Results}

We use a panel random effects model to estimate the linear probability that company $i$ looks for external equity in year $t{ }^{14}$ The results of different specifications are reported in Table 4. Companies' age and three sets of dummies capturing industry, country and year effects are included in all models. For each specification, we also show a model in which we include additional control variables to account for companyspecific and location-specific effects. When we consider these additional controls, the number of observations decreases because of missing values.

Let us focus on columns 1 and 2, in which we show the results of the weighted distance specification, including measures of the local availability of VC (i.e., within the home region of a focal company, i.e., VCavailability_local) and the distance-weighted availability of VC outside of the company's region but within national borders (VCavailability_national), and outside of the company's country (VCavailability_abroad). We also consider the level of competition in

\footnotetext{
${ }^{14}$ We preferred the random effects model to the fixed effects model for two reasons. First, a random effects model allowed us to better estimate the effect of our independent variables relating to the availability of VC, which are quite stable over time and vary mostly across companies/regions. For example, the between standard deviation of the variable VCavailability_local is approximately twice as large as its within standard deviation (1.777 and 0.938 , respectively). Second, and relatedly, our predictions about the effects of the geography of prospective VC investors on the demand for external equity relate more to differences in the availability of VC across regions (between differences) than on differences over time within the focal region (within differences). Note, however, that fixed effects estimates lead to results (available from the authors upon request) that are very similar to those presented in the text.
} 
Table 2

Variables description.

\begin{tabular}{|c|c|c|c|}
\hline & Variable & Description & Data source(s) \\
\hline 1 & VCseeking $_{i, t}$ & $\begin{array}{l}\text { Dummy equal to } 1 \text { in the year when the venture looked for external equity. To build this } \\
\text { variable we combined the questions Has your company ever sought equity financing from sources } \\
\text { other than founders, their family members and friends? and the question about the period of the } \\
\text { venture's life during which it sought external equity. }\end{array}$ & VICO survey \\
\hline 2 & VCavailability_local ${ }_{i, t-1}$ & $\begin{array}{l}\text { Logarithm of the sum of the number of investments made by VC investors headquartered in the } \\
\text { region of venture } i \text { in the time period }(t-3) \text { to } t-1 \text {. Only "new" investments are considered, } \\
\text { i.e., investments in which the VC investor financed a venture for the first time. }\end{array}$ & $\begin{array}{l}\text { Authors' elaboration based on } \\
\text { Thomson One }\end{array}$ \\
\hline \multirow[t]{2}{*}{3} & \multirow[t]{2}{*}{ VCavailability_national $_{i, t-1}$} & $\begin{array}{l}\text { A distance-weighted index of availability of VC investments outside the region where the } \\
\text { venture } i \text { is located but in the same country. It is calculated as: } \\
\log \sum_{l \in C_{i, t-1}, l \neq k_{i}} \text { (distance } e_{i, l, t-1}^{-\alpha} \text { VCavailability_local }_{i, t-1} \text { ) }\end{array}$ & \multirow[t]{2}{*}{$\begin{array}{l}\text { Authors' elaboration based on } \\
\text { Thomson One and GoogleMaps }\end{array}$} \\
\hline & & $\begin{array}{l}C_{i, t-1} \text { is the group of VC hubs of the country where the venture is located, } l \text { denotes each of } \\
\text { those VC hubs, distance } e_{i, l, t-1} \text { is the distance (in } 10 \mathrm{~km} \text { ) between venture's } i \text { location and the } \\
\text { centroid of the VC hub } l \text { (excluding the region where the venture is located - } k_{i} \text {, if it is a hub) } \\
\text { and } \alpha \text { is a decay factor for distance. }\end{array}$ & \\
\hline 4 & VCavailability_abroad $d_{i, t-1}$ & $\begin{array}{l}\text { A distance-weighted index of availability of VC investments outside the country where the } \\
\text { venture } i \text { is located. It is calculated as: } \\
\log \sum_{l \in C_{i, t-1}, l \neq k_{i}}\left(\text { distance }_{i, l, t-1}^{-\alpha}{ }^{*} \text { VCavailability_local }{ }_{i, t-1}\right)\end{array}$ & $\begin{array}{l}\text { Authors' elaboration based on } \\
\text { Thomson One and GoogleMaps }\end{array}$ \\
\hline & & $\begin{array}{l}C_{i, t-1}^{-} \text {is the group of VC hubs outside of the country where the venture } i \text { is located, } l \text { denotes } \\
\text { each of those hubs, distance } e_{i, l, t-1} \text { is the distance (in } 10 \mathrm{~km} \text { ) between venture's } i \text { location and the } \\
\text { centroid of the hub } l \text { and } \alpha \text { is a decay factor for distance. }\end{array}$ & \\
\hline 5 & VCavailability_national_a-b_km $m_{i, t-1}$ & $\begin{array}{l}\text { Logarithm of the sum of the number of investments in the time period }(t-3) \text { to } t-1 \text { made by } \\
\text { VC investors headquartered in the same country of the venture } i \text { and within a radius going from } \\
a \mathrm{~km} \text { to } b \mathrm{~km} \text { far from where the venture } i \text { is located. }\end{array}$ & $\begin{array}{l}\text { Authors' elaboration based on } \\
\text { Thomson One and GoogleMaps }\end{array}$ \\
\hline 6 & VCavailability_abroad_a-b_km $m_{i, t-1}$ & $\begin{array}{l}\text { Logarithm of the sum of the number of investments in the time period }(t-3) \text { to } t-1 \text { made by VC } \\
\text { investors headquartered outside of the country of the venture } i \text { and within a radius going from } a \\
\mathrm{~km} \text { to } b \mathrm{~km} \text { far from where the venture } i \text { is located. }\end{array}$ & $\begin{array}{l}\text { Authors' elaboration based on } \\
\text { Thomson One and GoogleMaps }\end{array}$ \\
\hline 7 & VCconcentration_local $l_{i, t-1}$ & $\begin{array}{l}\text { Concentration of new investments made by VC investors headquartered in the region of venture } \\
i \text { in the time period ( } t-3) \text { up to } t-1 \text {. It is measured by the C } 4 \text { index, i.e., the percentage of } \\
\text { investments made by the top } 4 \mathrm{VC} \text { investors in the time period }(t-3) \text { to } t-1 \text {. }\end{array}$ & $\begin{array}{l}\text { Authors' elaboration based on } \\
\text { Thomson One }\end{array}$ \\
\hline 8 & $\operatorname{age}_{i, t}$ & Logarithm of venture's age. & \\
\hline 9 & manager $_{i}$ & $\begin{array}{l}\text { Dummy equal to } 1 \text { if among the group of founders of the venture there were one or more } \\
\text { individuals who had managerial experience before founding the venture. }\end{array}$ & VICO survey \\
\hline 10 & serial $_{i}$ & $\begin{array}{l}\text { Dummy equal to } 1 \text { if among the group of founders of the venture there were one or more } \\
\text { individuals who had founded one or more other firms before founding the focal venture, i.e. } \\
\text { there was a serial entrepreneur(s). }\end{array}$ & VICO survey \\
\hline 11 & $M B A_{i}$ & $\begin{array}{l}\text { Dummy equal to } 1 \text { if among the group of founders of the venture there were one or more } \\
\text { individuals who had obtained an MBA or a master degree in Economics before founding the } \\
\text { venture. }\end{array}$ & VICO survey \\
\hline 12 & $P h D \_$science $_{i}$ & $\begin{array}{l}\text { Dummy equal to } 1 \text { if among the group of founders of the venture there were one or more } \\
\text { individuals who had obtained a PhD in technical or scientific disciplines before founding the } \\
\text { venture. }\end{array}$ & VICO survey \\
\hline 13 & 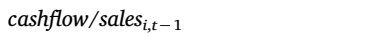 & Ratio between cash flow and sales, computed in the year $t-1$ & VICO dataset \\
\hline 14 & debt/totalassets ${ }_{i, t-1}$ & Ratio between total debt and total assets, computed in the year $t-1$. & VICO dataset \\
\hline 15 & CAPEX/assets ${ }_{i, t-1}$ & Ratio between capital expenditures and total assets, computed in the year $t-1$. & VICO dataset \\
\hline 16 & patent_stock $k_{i, t-1}$ & $\begin{array}{l}\text { Depreciated number of granted patents. Granted patents are assigned to the application year. } \\
\text { We use a } 0.15 \text { knowledge depreciation rate. }\end{array}$ & VICO dataset \\
\hline 17 & totalassets $_{i, t-1}$ & Total assets in the year $t-1$ & VICO dataset \\
\hline 18 & $d_{-}$accounting_missing ${ }_{i, t-1}$ & Dummy equal to 1 one the accounting information were missing. & VICO dataset \\
\hline 19 & debt_local $l_{, t-1}$ & $\begin{array}{l}\text { Average of debt to equity ratio for high-tech entrepreneurial ventures located in the region } k \\
\text { (NUTS2) of venture } i \text { in the year } t-1 \text {. }\end{array}$ & VICO dataset \\
\hline 20 & patents_local $l_{k, t-1}$ & Logarithm of the number of patents in the region $k$ (NUTS2) of venture $i$ in the year $t-1$. & Eurostat \\
\hline 21 & $G D P \_{ }_{-}{ }^{\prime} a l_{k, t-1}$ & Logarithm of the GDP in the region $k$ (NUTS2) of venture $i$ in the year $t-1$. & Eurostat \\
\hline 22 & area_local $k_{k, t-1}$ & Area of the region $k$ (NUTS2) where the company is located $\left(\mathrm{km}^{2}\right)$. & Eurostat \\
\hline 23 & $M S C I_{-}$national $l_{c, t-1}$ & $\begin{array}{l}\text { MSCI index measured at the national level. The Morgan Stanley Capital International index is a } \\
\text { measurement of stock market performance in a particular area. }\end{array}$ & Morgan Stanley \\
\hline 24 & bankruptcylaws_national $l_{c, t-1}$ & $\begin{array}{l}\text { Variable accounting for changes in bankruptcy laws. Specifically, following Armour and } \\
\text { Cumming (2004), Armour and Cumming (2008), the dummy is equal to } 1 \text { for country } c \text { in the } \\
\text { years in which there is a "time to discharge in bankruptcy", i.e., there is a given number of years } \\
\text { before a bankrupt individual would obtain a "fresh start". Armour and Cumming (2004) provide } \\
\text { such information for the period } 1984-2005 \text {. We have completed the time series till } 2009 \text { using } \\
\text { information retrieved from the International Insolvency Institute (https://www.iiglobal.org/). }\end{array}$ & $\begin{array}{l}\text { Armour and Cumming (2004), } \\
\text { Armour and Cumming (2008); } \\
\text { International Insolvency Institute }\end{array}$ \\
\hline 25 & infrastructures_national $l_{c, t-1}$ & $\begin{array}{l}\text { Variable accounting for the development of the transport infrastructures. It is computed ad the } \\
\text { number of } \mathrm{km} \text { of railways divided by the population. }\end{array}$ & Eurostat \\
\hline
\end{tabular}

the local VC market (inversely captured by VCconcentration_local).

As we expected, the local availability of VC has a positive effect on companies' propensity to look for external equity, as shown by the positive and significant coefficient (at the $1 \%$ confidence level) of VCavailability_local. VCavailability_national also has a positive and significant (at the $1 \%$ level) coefficient, while the coefficient of VCavailability_abroad is non-significant at standard confidence levels.
This result highlights that the availability of VC beyond national borders does not influence the external equity-seeking behaviour of companies. Contrary to our prediction, entrepreneurial ventures' propensity to seek external equity does not appear to be significantly affected by the level of competition in the local VC market. The coefficient of VCconcentration_local is negative as expected, but not significant.

To investigate the economic magnitude of the effects illustrated 


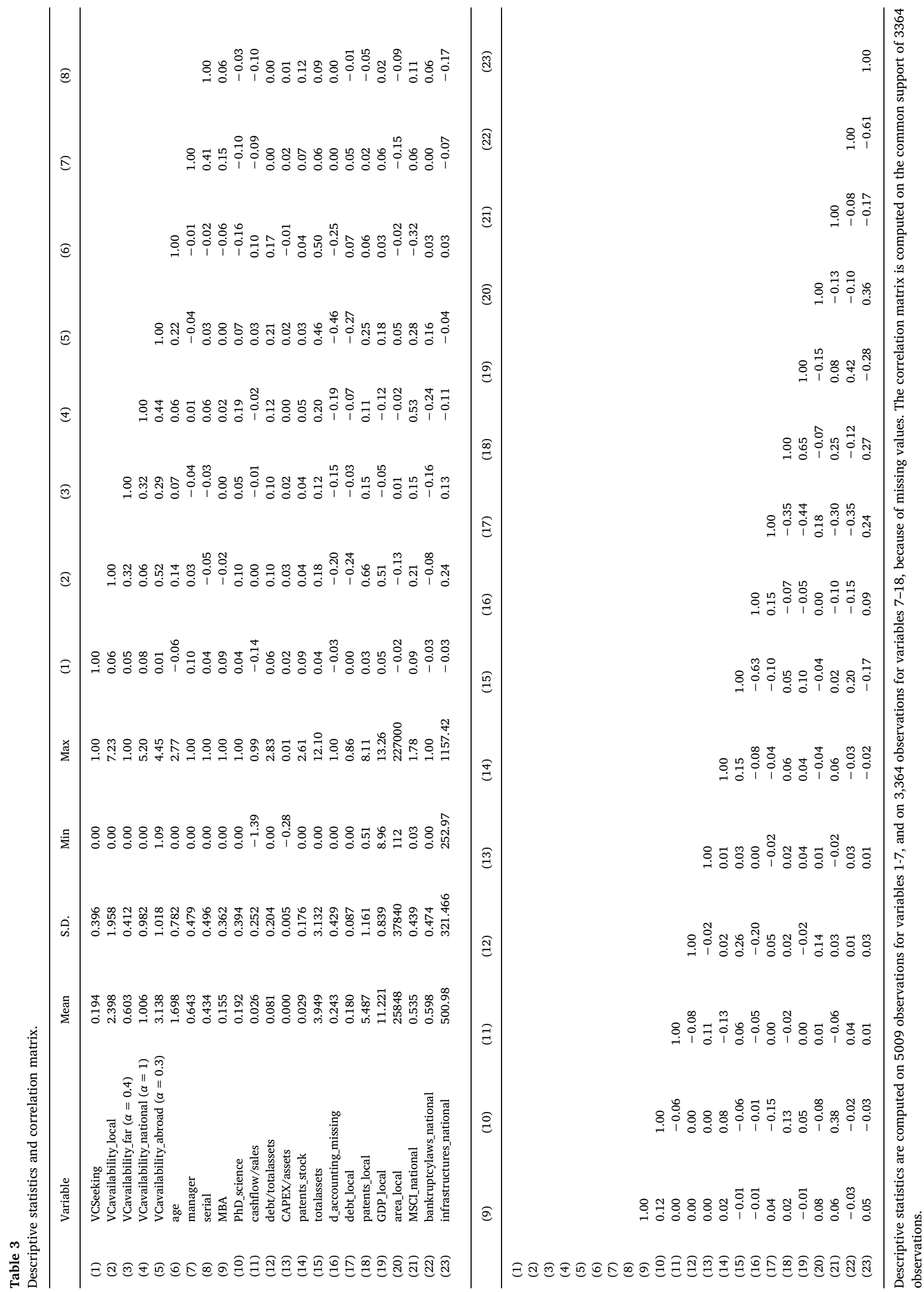


Table 4

Seeking external equity: panel random-effects models.

\begin{tabular}{|c|c|c|c|c|c|c|}
\hline & (1) & (2) & (3) & (4) & $(5)$ & (6) \\
\hline VCavailability_local & $\begin{array}{l}0.014^{* * * \pi} \\
(0.005)\end{array}$ & $\begin{array}{l}0.025^{\text {taxth }} \\
(0.009)\end{array}$ & & & & \\
\hline VCavailability_national $(\alpha=1)$ & $\begin{array}{l}0.051^{\text {. }} \\
(0.012)\end{array}$ & $\begin{array}{l}0.058^{\text {knde }} \\
(0.016)\end{array}$ & & & & \\
\hline VCavailability_abroad ( $\alpha=0.3)$ & $\begin{array}{l}0.026 \\
(0.060)\end{array}$ & $\begin{array}{c}-0.011 \\
(0.114)\end{array}$ & & & & \\
\hline VCavailability_national_0-50_km & & & $\begin{array}{l}0.013^{k *} \\
(0.005)\end{array}$ & $\begin{array}{l}0.017^{k * k} \\
(0.007)\end{array}$ & $\begin{array}{l}0.013^{k * k} \\
(0.005)\end{array}$ & $\begin{array}{l}0.017^{k / k} \\
(0.007)\end{array}$ \\
\hline VCavailability_national_50-250_km & & & $\begin{array}{l}0.015^{* *} \\
(0.006)\end{array}$ & $\begin{array}{l}0.016^{*} \\
(0.008)\end{array}$ & $\begin{array}{l}0.014 \\
(0.006)\end{array}$ & $\begin{array}{l}0.015^{*} \\
(0.008)\end{array}$ \\
\hline VCavailability_national_250-500_km & & & $\begin{array}{l}-0.003 \\
(0.006)\end{array}$ & $\begin{array}{l}-0.004 \\
(0.009)\end{array}$ & $\begin{array}{c}-0.001 \\
(0.006)\end{array}$ & $\begin{array}{l}-0.002 \\
(0.008)\end{array}$ \\
\hline VCavailability_national_500-1000_km & & & $\begin{array}{l}0.008 \\
(0.005)\end{array}$ & $\begin{array}{l}0.004 \\
(0.007)\end{array}$ & & \\
\hline VCavailability_national_1000-5000_km & & & $\begin{array}{l}-0.014 \\
(0.026)\end{array}$ & $\begin{array}{l}-0.012 \\
(0.041)\end{array}$ & & \\
\hline VCavailability_abroad_0-50_km & & & $\begin{array}{l}-0.024 \\
(0.020)\end{array}$ & $\begin{array}{l}-0.027 \\
(0.028)\end{array}$ & & \\
\hline VCavailability_abroad_50-250_km & & & $\begin{array}{c}-0.001 \\
(0.005)\end{array}$ & $\begin{array}{l}-0.011 \\
(0.007)\end{array}$ & & \\
\hline VCavailability_abroad_250-500_km & & & $\begin{array}{l}0.005 \\
(0.006)\end{array}$ & $\begin{array}{l}0.015 \\
(0.010)\end{array}$ & & \\
\hline VCavailability_abroad_500-1000_km & & & $\begin{array}{l}0.004 \\
(0.010)\end{array}$ & $\begin{array}{l}0.014 \\
(0.014)\end{array}$ & & \\
\hline VCavailability_abroad_1000-5000_km & & & $\begin{array}{l}0.009 \\
(0.021)\end{array}$ & $\begin{array}{l}-0.032 \\
(0.040)\end{array}$ & & \\
\hline VCavailability_abroad_0-500_km & & & & & $\begin{array}{l}0.001 \\
(0.006)\end{array}$ & $\begin{array}{l}0.013 \\
(0.009)\end{array}$ \\
\hline VCconcentration_local & $\begin{array}{l}-0.013 \\
(0.014)\end{array}$ & $\begin{array}{l}-0.029 \\
(0.019)\end{array}$ & $\begin{array}{l}0.007 \\
(0.013)\end{array}$ & $\begin{array}{l}0.006 \\
(0.018)\end{array}$ & & \\
\hline age & $\begin{array}{l}0.003 \\
(0.010)\end{array}$ & $\begin{array}{l}0.045^{\text {. }} \\
(0.016)\end{array}$ & $\begin{array}{l}0.003 \\
(0.010)\end{array}$ & $\begin{array}{l}0.045^{k} \\
(0.016)\end{array}$ & $\begin{array}{l}0.003 \\
(0.010)\end{array}$ & $\begin{array}{l}0.047^{\text {knkx }} \\
(0.016)\end{array}$ \\
\hline manager & & $\begin{array}{l}0.077^{* k} \\
(0.033)\end{array}$ & & $\begin{array}{l}0.075^{1} \\
(0.033)\end{array}$ & & $\begin{array}{l}0.075^{2 k} \\
(0.034)\end{array}$ \\
\hline serial & & $\begin{array}{l}-0.065^{* *} \\
(0.031)\end{array}$ & & $\begin{array}{l}-0.060^{*} \\
(0.031)\end{array}$ & & $\begin{array}{l}-0.061 \\
(0.031)\end{array}$ \\
\hline MBA & & $\begin{array}{l}0.085^{\text {*ke }} \\
(0.038)\end{array}$ & & $\begin{array}{l}0.084^{*} \\
(0.038)\end{array}$ & & $\begin{array}{l}0.084^{2} \\
(0.038)\end{array}$ \\
\hline PhD_science & & $\begin{array}{l}0.061 \\
(0.039)\end{array}$ & & $\begin{array}{l}0.061 \\
(0.039)\end{array}$ & & $\begin{array}{l}0.058 \\
(0.040)\end{array}$ \\
\hline cashflow/sales & & $\begin{array}{l}-0.123^{\text {. }} \\
(0.024)\end{array}$ & & $\begin{array}{l}-0.121^{\text {* }} \\
(0.024)\end{array}$ & & $\begin{array}{l}-0.122^{2 k x} \\
(0.024)\end{array}$ \\
\hline debt/totalassets & & $\begin{array}{l}0.011 \\
(0.032)\end{array}$ & & $\begin{array}{l}0.012 \\
(0.032)\end{array}$ & & $\begin{array}{l}0.012 \\
(0.032)\end{array}$ \\
\hline CAPEX/assets & & $\begin{array}{l}1.238 \\
(1.050)\end{array}$ & & $\begin{array}{l}1.227 \\
(1.050)\end{array}$ & & $\begin{array}{l}1.235 \\
(1.048)\end{array}$ \\
\hline patents_stock & & $\begin{array}{l}0.091^{* *} \\
(0.044)\end{array}$ & & $\begin{array}{l}0.079 \\
(0.044)\end{array}$ & & $\begin{array}{l}0.080 \\
(0.044)\end{array}$ \\
\hline totalassets & & $\begin{array}{l}0.003 \\
(0.003)\end{array}$ & & $\begin{array}{l}0.003 \\
(0.003)\end{array}$ & & $\begin{array}{l}0.003 \\
(0.003)\end{array}$ \\
\hline d_accounting_missing & & $\begin{array}{l}0.011 \\
(0.018)\end{array}$ & & $\begin{array}{l}0.010 \\
(0.018)\end{array}$ & & $\begin{array}{l}0.011 \\
(0.018)\end{array}$ \\
\hline debt_local & & $\begin{array}{l}0.217^{\text {thk }} \\
(0.092)\end{array}$ & & $\begin{array}{l}0.238^{k * k} \\
(0.093)\end{array}$ & & $\begin{array}{l}0.238^{k * k} \\
(0.093)\end{array}$ \\
\hline patents_local & & $\begin{array}{l}-0.034 \\
(0.022)\end{array}$ & & $\begin{array}{l}-0.056 \\
(0.023)\end{array}$ & & $\begin{array}{l}-0.043^{2} \\
(0.023)\end{array}$ \\
\hline GDP_local & & $\begin{array}{l}0.048 \\
(0.038)\end{array}$ & & $\begin{array}{l}0.069^{*} \\
(0.038)\end{array}$ & & $\begin{array}{l}0.058 \\
(0.037)\end{array}$ \\
\hline area_local & & $\begin{array}{l}0.000 \\
(0.000)\end{array}$ & & $\begin{array}{l}0.000 \\
(0.000)\end{array}$ & & $\begin{array}{l}0.000 \\
(0.000)\end{array}$ \\
\hline MSCI_national & & $\begin{array}{l}0.209^{\text {winkex }} \\
(0.061)\end{array}$ & & $\begin{array}{l}0.210^{* \text { ink* }} \\
(0.061)\end{array}$ & & $\begin{array}{l}0.211^{k n k x} \\
(0.062)\end{array}$ \\
\hline bankruptcylaws_national & & $\begin{array}{l}0.002 \\
(0.038)\end{array}$ & & $\begin{array}{l}-0.004 \\
(0.035)\end{array}$ & & $\begin{array}{l}-0.006 \\
(0.034)\end{array}$ \\
\hline infrastructures_national & & $\begin{array}{l}-0.001 \\
(0.001)\end{array}$ & & $\begin{array}{l}-0.000 \\
(0.001)\end{array}$ & & $\begin{array}{l}-0.001 \\
(0.001)\end{array}$ \\
\hline Constant & $\begin{array}{l}0.022 \\
(0.221)\end{array}$ & $\begin{array}{c}-0.471 \\
(0.526)\end{array}$ & $\begin{array}{c}-0.009 \\
(0.210)\end{array}$ & $\begin{array}{c}-0.640 \\
(0.575)\end{array}$ & $\begin{array}{l}0.139 \\
(0.084)\end{array}$ & $\begin{array}{c}-0.615 \\
(0.458)\end{array}$ \\
\hline
\end{tabular}




\begin{tabular}{|c|c|c|c|c|c|c|}
\hline & (1) & (2) & (3) & (4) & (5) & (6) \\
\hline Country dummies & Yes & Yes & Yes & Yes & Yes & Yes \\
\hline Industry dummies & Yes & Yes & Yes & Yes & Yes & Yes \\
\hline Year dummies & Yes & Yes & Yes & Yes & Yes & Yes \\
\hline $\mathrm{N}$ observations & 5101 & 3412 & 5101 & 3412 & 5101 & 3412 \\
\hline $\mathrm{N}$ groups & 533 & 404 & 533 & 404 & 533 & 404 \\
\hline $\mathrm{R} 2$ & 0.03 & 0.06 & 0.03 & 0.06 & 0.03 & 0.06 \\
\hline
\end{tabular}

The table reports coefficients and standard errors (in brackets) of panel random effects models whose dependent variable is VCseeking.

* Significance levels: $p<0.10$.

** Significance levels: $p<0.05$.

$* * *$ Significance levels: $p<0.01$.

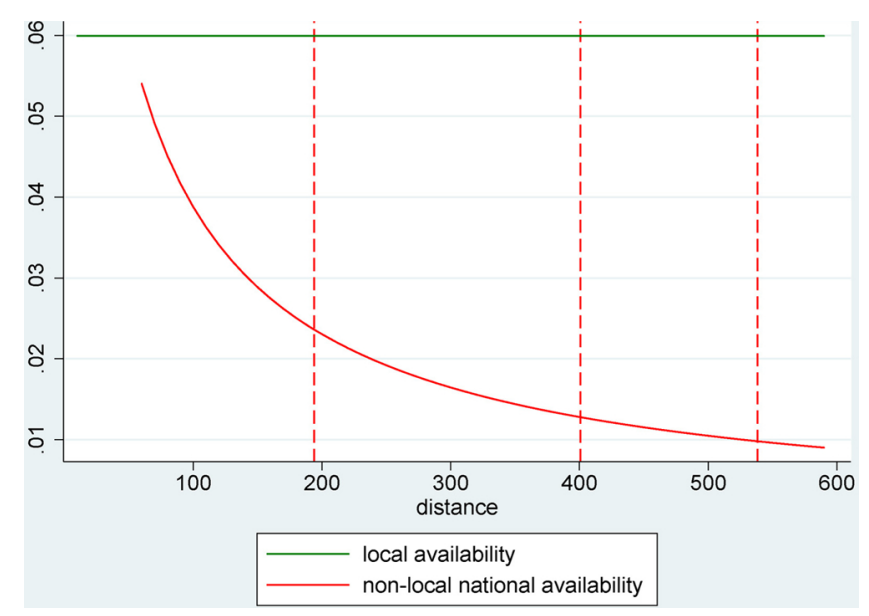

Fig. 4. The estimated effects of VC availability and distance on ventures' propensity to search external equity. The figure shows the change in a venture's propensity to seek external equity for a change in the number of new investments in a NUTS2 region within national borders ("non-local national availability" line) from 1 to 21 (respectively equal to the 25th and the 75th percentiles of the distribution), depending on geographic distance between the venture's location and the centroid of the focal region. For the sake of comparison we also report the effect generated by the same increase of the number of new VC investments on the external equity seeking behavior of ventures located in the same region (see the "local availability" line). The vertical dotted lines represent the 25th, 50th and 75th percentile of the distribution of the distance of venture's location from the 50 VC hubs.

above, let us consider Fig. 4. Based on the estimates presented in column 2 of Table 4, the figure shows the increase in the probability that a company seeks external equity triggered by an increase in VC availability. Specifically, to measure the magnitude of the effect on the demand for external equity of the local availability of VC, we consider an increase in the number of VC investments in the same region as the focal company. To measure the magnitude of the effect of the national availability of VC and its distance decay, we consider an increase in the number of VC investments in a different region from the one of the focal company but in the same country. In both cases we consider an increase of $20 \mathrm{VC}$ investments, equal to a change from the 25th (1) to the 75th (21) percentile of the number of new investments in a 3 year period over all NUTS2 regions. The shock in local VC availability leads to a 6.0 percentage-point increase in the likelihood that a company seeks external equity in a given year. ${ }^{15}$ Since the unconditional probability of looking for external equity in our sample is equal to $19.4 \%$ (see

\footnotetext{
${ }^{15}$ This increase is computed as 0.025 (i.e., the coefficient of VCavailability_local in column 2 of Table 4) multiplied by the shock in local availability $(\log (21+1)-\log (1+1))$.
}

Table 3), this increase is sizable. The effect of a shock in the availability of $\mathrm{VC}$ in the region in which a company is located is always greater than that of a similar shock in another region of the same country. An increase of 20 investments in a VC hub leads to a 3.9 percentage-point increase in the probability that a company located $100 \mathrm{~km}$ from that hub looks for external equity. The increase shrinks to 1.9 for companies located $250 \mathrm{~km}$ away, and progressively vanishes at greater distance.

In columns 3 and 4, we show the results of the radius specification. We find a positive and significant coefficient for VCavailability_national_0_50_km (at the 5\% level) and for VCavailability_national_50_250_km (at the $5 \%$ or $10 \%$ level), while variables capturing the availability of VC at higher distances or across borders are not significant. In line with the evidence from the weighted distance models, we find that companies are significantly more inclined to look for external equity if they are located near areas in which VC is more active. Prospective VC investors located further than $250 \mathrm{~km}$ and those beyond national borders have no effect on companies' demand for external equity, independently of the number of investments they make. As in the previous specification, the coefficient of VCconcentration_local is negative but not significant.

Some further tests on the coefficients of model 4 confirm that the coefficients of VCavailability_national_500_1000_km and VCavailability_national_1000_5000_ $\mathrm{km}$ are jointly insignificant $\left(\chi^{2}(2)=0.42, \quad p\right.$-value $\left.=0.8086\right)$. Similarly, the coefficients of VCavailability_abroad_500_1000_ $\mathrm{km}$ and VCavailability_abroad_ $100 \__{-} 5000_{-} \mathrm{km}$ are jointly insignificant $\left(\chi^{2}(2)=2.46\right.$, $p$-value $=0.2918$ ). Therefore, in columns 5 and 6 , we show a more compact version of the radius specification in which we drop these insignificant variables. We decided not to drop all the variables capturing VC availability across national borders but rather to aggregate the variables VCavailability_abroad_0_50_ $\mathrm{km}$, VCavailability_abroad_ $50 \_250 \_\mathrm{km}$ and VCavailability_abroad_250_500_ $\mathrm{km}$ in a single variable: VCavailability_abroad_0_500_ $\mathrm{km}$. This parsimonious specification reflects the fact that according to the results of the "weighted distance" specification, geographic distance plays a less important role across borders. Results on this specification, shown in columns 5 and 6 , confirms the previous findings: only the availability of VC within a radius of $250 \mathrm{~km}$ and within the borders of the country in which a focal company is located influence its demand for external equity.

Let us turn our attention to the control variables. The human capital of the founders positively affects companies' propensity to look for external equity (Eckhardt et al., 2006). Indeed, manager and $M B A$ are positively and significantly (at the $5 \%$ level) associated with the dependent variable in columns 2, 4 and 6 . Instead, serial has negative coefficients in all models in which it is included (at the $5 \%$ or $10 \%$ level), possibly as a result of the greater internal financial resources of serial entrepreneurs. Companies with more cash flow are significantly (at the $1 \%$ level) less likely to look for external equity. This result is in line with the pecking order theory, according to which companies prefer to finance new projects with internal cash flows without 
Table 5

Seeking external equity: robustness checks with weighted specification, panel random-effects models.

\begin{tabular}{|c|c|c|c|c|c|c|c|}
\hline & $\begin{array}{l}\text { (1) } \\
\text { Without firms } \\
\text { seeking at } \\
\text { foundation }\end{array}$ & $\begin{array}{l}\text { (2) } \\
\text { Without firms } \\
\text { not needing }\end{array}$ & $\begin{array}{l}\text { (3) } \\
\text { On matched } \\
\text { sample }\end{array}$ & $\begin{array}{l}\text { (4) } \\
\text { Without VC- } \\
\text { backed firms }\end{array}$ & $\begin{array}{l}(5) \\
\text { With IMR on } \\
\text { response }\end{array}$ & $\begin{array}{l}\text { (6) } \\
\text { Excluding } \\
\text { bubble period }\end{array}$ & $\begin{array}{l}\text { (7) } \\
\text { Using invested- } \\
\text { firm location }\end{array}$ \\
\hline VCavailability_local & $\begin{array}{l}0.018 \\
(0.009)\end{array}$ & $\begin{array}{l}0.041^{k+k+k} \\
(0.013)\end{array}$ & $\begin{array}{l}0.043^{* * *} \\
(0.021)\end{array}$ & $\begin{array}{l}0.019^{k+1 \times} \\
(0.008)\end{array}$ & $\begin{array}{l}0.029^{* k x} \\
(0.007)\end{array}$ & $\begin{array}{l}0.016^{*} \\
(0.010)\end{array}$ & \\
\hline VCavailability_national $(\alpha=1)$ & $\begin{array}{l}0.036 \\
(0.017)\end{array}$ & $\begin{array}{l}0.084^{\text {secke }} \\
(0.023)\end{array}$ & $\begin{array}{l}0.056 \\
(0.033)\end{array}$ & $\begin{array}{l}0.050^{3 \times k} \\
(0.016)\end{array}$ & 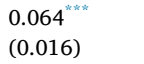 & $\begin{array}{l}0.057^{\text {2*xk }} \\
(0.017)\end{array}$ & \\
\hline VCavailability_abroad $(\alpha=0.3)$ & $\begin{array}{l}-0.181 \\
(0.120)\end{array}$ & $\begin{array}{l}-0.003 \\
(0.164)\end{array}$ & $\begin{array}{l}0.197 \\
(0.274)\end{array}$ & $\begin{array}{l}0.045 \\
(0.111)\end{array}$ & $\begin{array}{l}0.017 \\
(0.133)\end{array}$ & $\begin{array}{l}0.015 \\
(0.117)\end{array}$ & \\
\hline $\begin{array}{l}\text { VCavailability_local (using invested- } \\
\text { companies location) }\end{array}$ & & & & & & & $\begin{array}{l}0.016^{*} \\
(0.009)\end{array}$ \\
\hline $\begin{array}{l}\text { VCavailability_national ( } \alpha=1 \text { ) (using } \\
\text { invested-companies location) }\end{array}$ & & & & & & & $\begin{array}{l}0.245^{\text {knk }} \\
(0.101)\end{array}$ \\
\hline $\begin{array}{l}\text { VCavailability_abroad ( } \alpha=0.3 \text { ) (using } \\
\text { invested-companies location) }\end{array}$ & & & & & & & $\begin{array}{l}-0.187 \\
(0.182)\end{array}$ \\
\hline VCconcentration_local & $\begin{array}{l}-0.028 \\
(0.020)\end{array}$ & $\begin{array}{l}-0.028 \\
(0.028)\end{array}$ & $\begin{array}{l}-0.068 \\
(0.038)\end{array}$ & $\begin{array}{l}-0.001 \\
(0.019)\end{array}$ & $\begin{array}{l}-0.030 \\
(0.017)\end{array}$ & $\begin{array}{l}-0.031 \\
(0.021)\end{array}$ & \\
\hline age & $\begin{array}{l}0.070^{\text {takck }} \\
(0.023)\end{array}$ & $\begin{array}{l}0.070^{\text {kelk }} \\
(0.023)\end{array}$ & $\begin{array}{l}0.092^{\text {inkth }} \\
(0.032)\end{array}$ & $\begin{array}{l}0.042^{\text {theke }} \\
(0.016)\end{array}$ & $\begin{array}{l}0.072^{* * * x} \\
(0.013)\end{array}$ & $\begin{array}{l}0.048^{\text {*kxk }} \\
(0.018)\end{array}$ & $\begin{array}{l}0.047^{1 . \pm \times k} \\
(0.016)\end{array}$ \\
\hline Inverse Mills Ratio & & & & & $\begin{array}{l}-0.593^{k+k * k} \\
(0.029)\end{array}$ & & \\
\hline Constant & $\begin{array}{l}0.163 \\
(0.569)\end{array}$ & $\begin{array}{l}-0.773 \\
(0.710)\end{array}$ & $\begin{array}{l}-2.528^{* *} \\
(1.237)\end{array}$ & $\begin{array}{l}-0.551 \\
(0.536)\end{array}$ & $\begin{array}{l}0.859^{*} \\
(0.506)\end{array}$ & $\begin{array}{l}-0.599 \\
(0.558)\end{array}$ & $\begin{array}{l}-0.359 \\
(0.604)\end{array}$ \\
\hline Year dummies & Yes & Yes & Yes & Yes & Yes & Yes & Yes \\
\hline Country dummies & Yes & Yes & Yes & Yes & Yes & Yes & Yes \\
\hline Industry dummies & Yes & Yes & Yes & Yes & Yes & Yes & Yes \\
\hline $\mathrm{HC}$ variables & Yes & Yes & Yes & Yes & Yes & Yes & Yes \\
\hline Local variables & Yes & Yes & Yes & Yes & Yes & Yes & Yes \\
\hline Accounting variables & Yes & Yes & Yes & Yes & Yes & Yes & Yes \\
\hline $\mathrm{N}$ observations & 2867 & 2314 & 1048 & 2801 & 3412 & 2922 & 3412 \\
\hline $\mathrm{N}$ groups & 329 & 307 & 258 & 264 & 404 & 381 & 404 \\
\hline $\mathrm{R} 2$ & 0.06 & 0.08 & 0.12 & 0.09 & 0.14 & 0.06 & 0.06 \\
\hline
\end{tabular}

The table reports coefficients and standard errors (in brackets) of panel random effects models whose dependent variable is VCseeking.

* Significance levels: $p<0.10$.

** Significance levels: $p<0.05$.

$* * *$ Significance levels: $p<0.01$.

resorting to more expensive external sources of capital (Cosh et al., 2009; Myers, 1984). Companies with greater patent stock are more likely to seek external equity (significant at the $5 \%$ or $10 \%$ level), a result in contrast with what Mina et al. (2013) found in their sample of UK and US firms. With respect to local conditions, we find a positive and significant (at the $5 \%$ level) effect of the local availability of debt, which proxies for the financial sophistication of the region, and of the MSCI index (at the 1\% level), capturing the development of financial markets at the country level. Similarly, regional GDP has a positive but far less significant coefficient ( $10 \%$ level, only in column 4$)$. Unexpectedly, we find a negative and significant (at the $5 \%$ level in column 4 and at the $10 \%$ level in column 6) coefficient for the logarithm of patents in the region. One possible explanation is that more innovative regions may have more comprehensive support systems in place for high-tech entrepreneurial ventures, partially compensating for the need for external equity. Finally, the older companies in our sample are more likely to seek external equity, as age has positive and significant coefficients at the $1 \%$ level in columns 2,4 and 6 .

\section{Robustness checks}

We performed several robustness checks based on the weighted distance specification, which we show in Table 5. Robustness checks based on the radius specification are shown in Table A1 in Appendix A. Results are similar across the two specifications and consistent with the estimates illustrated earlier, with few exceptions (e.g., the lower statistical significance of the VC_availability_national_50_250 variable in the radius specification).

The first concern one could raise is that potential reverse causality between companies' location and demand for external equity may lead to endogeneity issues. A company actively seeking external equity may decide to locate closer to prospective VC investors. Previous studies indicate that the location of new companies is mainly driven by factors other than the availability of VC. Michelacci and Silva (2007) document that entrepreneurs are affected by a local bias, i.e., they are inclined to establish their businesses in their home region. Moreover, Dahl and Sorenson (2012) find that ventures perform better when they are 
located in the home region of their founders. In high-tech sectors, the location of newly created ventures is largely explained by the geographical distribution of skilled human capital (e.g., talented inventors) rather than by the geography of VC. For example, studies on biotech start-ups (Audretsch and Stephan, 1996; Zucker et al., 1998) show that in most cases, U.S. university scientists located their newly created biotech ventures in the region where the university with which they were affiliated was located. Still, Stuart and Sorenson (2003) find that that the concentration of VC investors in a region positively influences the founding rates of US-based biotech ventures, but the effect is much weaker in magnitude and significance than the effects of the concentration of universities or the concentration of other biotech firms. Lastly, Bertoni et al. (2018) confirm the local bias of Italian entrepreneurs and document that relocation from the home region is very rare and not driven by the availability of VC.

We conduct a robustness check to assess the effect on our estimates of the potential reverse causality between entrepreneurial ventures' location choices and demand for VC. One can assume that companies that did not look for external equity at or before their founding are unlikely to have selected their initial location based on the availability of VC. Therefore, we re-estimated the model excluding companies that indicated in the survey questionnaire that they had looked for external equity at or before their founding. To balance the sample, we also excluded observations at foundation for companies that did not seek external equity, obtaining a sample of 329 companies. The results are reported in column 1 of Table 5. Both VCavailability_local and VCavailability _national still have positive and significant coefficients (at the $5 \%$ level), suggesting that reverse causality between initial location and demand for external equity does not drive our results.

Furthermore, we investigate whether companies re-locate after foundation to increase their probability of success in seeking VC. To tackle this issue, we study a sample of 332 companies included in the VICO database and founded in 2003 or 2004 for which we were able to track the location between foundation and 2009. Information on location at foundation and location in 2009 was retrieved using historical versions of the Orbis database (the database traces companies' locations since 2003). 90 companies out of 332 (27.1\%) relocated between foundation and 2009. We first test whether the geographical distribution of prospective VC investors influences the probability of relocating. We find that VCavailability_local and VCavailability_national, measured in the location at foundation, are not significantly different for the companies that relocated with respect to other companies ( $t$ test $=0.5481, \quad p$-value $=0.5840 \quad$ for $\quad$ VCavailability_local; $t$ test $=0.6506, p$-value $=0.5222$ for VCavailability_national). These results suggest that companies located in regions with less $\mathrm{VC}$ or that are more distant from VC hubs are not more likely to relocate than other companies. We then focus on companies that relocated in the first years of their lives and compared the local and national availability of VC in the initial and final locations. We find that companies do not relocate in regions where there is greater availability VC. Indeed, the local and national availabilities of VC in the new location are significantly lower than those in the initial location (VCavailability_local and VCavailability_national decrease by $39.6 \%$ and $40.3 \%$, respectively, with both differences being significant at the $1 \%$ level). Rental prices, which are cheaper in non-metropolitan areas (i.e., outside VC hubs), may explain our results and are a more important driver of relocation than the availability of VC at close distance. Finally, we tested whether relocating has an impact on the probability of receiving VC, finding that it is not the case: the share of companies that obtain VC is the same for companies that relocated as for companies that did not $(t-$ test $=-0.3709, p$-value $=0.7109$ ). These results confirm that at least in the period and geographical regions under analysis, relocation to VC hubs is not a strong source of reverse causality between the local availability of VC and companies' demand for VC, and does not threaten the validity of our results.

A second concern may be that our sample contains companies that did not look for external equity simply because they were unlikely to receive VC, for instance, because of their limited quality or growth orientation, regardless of their location. We believe that in our sample this issue is limited, as the VICO database was created with the specific objective of including companies that potentially would be a target for VC investment (e.g., based on their industry, age and size), independently of whether or not they obtained VC (Bertoni and Martí, 2011). Moreover, we include an ample set of company-specific controls, including human capital variables that should account for the quality of the business. Nevertheless, we conduct several robustness checks to ensure that companies that would not be suitable candidates for a VC investment are not affecting our results.

First, we replicate the analysis excluding 106 companies that did not seek external equity because they did not need any external financing (self-reported information collected in the survey in 2010). These companies might be less growth-oriented than other sample companies. This is a conservative approach because arguably, these companies might have chosen a business model compatible with absence of VC due to the geographic distance from prospective VC investors. Results reported in column 2 are unaffected by the exclusion of these companies.

Second, we replicate our analysis on a sample of companies with similar estimated probabilities of receiving VC. ${ }^{16}$ We build the sample by matching VC-backed companies with non-VC-backed twins. This approach is in line with the suggestion of Ho et al. (2007) to use matching as a pre-processing technique to reduce the potential for confounding bias. We first compute the probability that a company is actually financed by VC investors, i.e., the propensity score. Specifically, we use all company-year observations for non-VC-backed companies and the company-year observations in the year of receipt of the first VC round for VC-backed companies. In this sample, we estimate a probit model with age, industry and year dummy variables (whose values are non-missing for all company-year observations) and predict the estimated probability of receiving VC. Then, we use the propensity score to match each VC-backed company in the year of receipt of VC with one non-VC-backed company with a similar probability of obtaining VC. One-to-one matching is done without replacement; i.e., a non-VC-backed company is not eligible to be matched more than once. We restrict the matched sample imposing the company-year observations to be in the common support; i.e., we drop observations whose estimated propensity score is higher than the maximum or lower than the minimum propensity score of VC-backed companies. This matching approach allows us to reduce uncontrolled heterogeneity in our sample. We ended with 158 VC-backed companies and 158 non-VC-backed twins. Finally, we include in the analysis all observations of VC-backed companies and their matched twins until the year of the matching, and we exclude observations after that year. We check that our matched sample has acceptable balancing properties by graphing the distribution of the pre- and post-matching propensity scores. The results of the models estimated using the matched sample are reported in column 3. The number of observations drops because of missing values in the control variables. The effects of the availability of VC are similar to those illustrated above.

Third, we discard all VC-backed companies and repeat the estimates on a sample composed only of companies that did not obtain VC. This sample is likely to be more homogeneous than the initial sample in terms of companies' attractiveness to VC investors. Results are shown in

\footnotetext{
${ }^{16}$ An even more conservative approach to select a sample of companies attractive to VC investors would be to discard all companies that did not receive VC and focus only on those that did. Unfortunately, this robustness check is not feasible because of the severe drop in observations when considering VCbacked companies only.
} 
column 4 of Table 5 and are once again robust, indicating that our results on the association between the geography of VC and companies' demand for external equity are not driven by companies that successfully obtained VC.

As a third robustness check, we acknowledge that the survey-based nature of our study potentially creates non-respondent bias concerns. Respondents may be systematically different from non-respondents, and this might have an impact on our results. To tackle this issue, we use a Heckman approach to account for any response bias that can emerge from the data. Based on a dataset including all companies in the VICO database to which the 2010 survey was administered, we estimate a probit model whose dependent variable is a dummy equal to 1 for respondents and 0 for non-respondents. We use as regressors companies' age in 2010, country and industry dummies, and a dummy equal to 1 for VC-backed companies and 0 for companies that were not VCbacked at the time of the survey. We use the results of the probit model to predict the probability of responding to the survey. Finally, we include the Inverse Mills Ratio calculated from the estimates of the selection equation in the main analysis to control for response bias (Heckman, 1979). We also bootstrapped to obtain reliable standard errors. The significant (and negative) coefficient of the IMR suggests that unobserved factors that are positively associated with the probability that companies will respond to the survey (resulting in a negative IMR) are positively associated with the probability that they will seek external equity. Our results related to the main independent variables remain unchanged (column 5 in Table 5), confirming that we can exclude the possibility that response bias is driving our results.

Our fourth robustness check relates to the fact that our observation period includes the years of the so-called Internet bubble (i.e. years 2000 and 2001). According to the data we showed earlier, both the number of VC investments and the propensity of sample companies to look for external equity peaked in this period. One may wonder whether our results are driven by companies' external equity seeking behaviour during the Internet bubble period. For this purpose, we rerun our estimates after dropping all observations relating to the years 2000 and 2001. As shown in column 6 of Table 5, results remain almost unchanged.

Our last robustness check is motivated by the fact that we define VC availability based on the headquarters of the VC firms, as reported by Thomson One. However, many VC firms are multi-office, with branches located in several regions and even countries. This may create distortions in our VC availability variables, as we may have allocated some investments to the wrong location. Unfortunately, we do not have information about which VC firms have multiple offices, and therefore we cannot check whether our results hold once we exclude these VC firms from the analysis. Therefore, we use an alternative approach and define VC availability not based on the location of the VC firms but based on the location of the target companies. Results based on this alternative approach are shown in column 7 of Table 5 and are similar to those illustrated earlier. ${ }^{17}$

\section{Additional analysis}

In this section we investigate the effects of several moderators of the relationship between the geography of prospective VC investors and companies' demand for external equity. We focus on the ownership and

\footnotetext{
${ }^{17}$ Notwithstanding the issue related to the location of the headquarter, we believe that the variables used in the main analysis, based on the location of prospective VC investors, are better in capturing costs and benefits associated with VC investment (which ultimately depend on the geographic distance of entrepreneurial ventures from prospective VC investors, not their portfolio companies). Moreover, to entrepreneurs considering external equity financing, the location of the portfolio companies may be less evident than the location of VC investors.
}

governance of VC investors and their reputation and on the institutional and cultural distance between the country of the focal company and those of VC investors. For this analysis, we use the compact radius specification. Indeed, the need to simultaneously calibrate several distance parameters makes the use of the "weighted distance" specification not viable, because of the high computational burden and the possible presence of several local optimal points. Moreover, because of multicollinearity problems, we are forced to reduce the number of regressors and use the compact version of the radius specification, in which we introduce the different moderators in the estimates one by one.

For what concerns VC ownership, we separately consider independent VC (IVC) investors and governmental VC (GVC investors). In Europe, IVC and GVC investors are more active than other investor types such as corporate and bank-affiliated VC investors (Bertoni et al., 2015). Moreover, for these two latter types of VC investors, the problem generated by the assignment of VC investments to the location of their headquarters is even more serious than for other VC types, because they are affiliated to companies and banks that may have multiple branches in different countries. Therefore, we excluded them from this analysis. For IVC, we generate the variables IVCavailability _national_0_50_ $\mathrm{km}$, IVCavailability_national_50_250_ $\mathrm{km}$ and IVCavailability_national_ $250 \_500 \_\mathrm{km}$ which measure the log of the number of new investments made by IVC investors located between 0 and 50, 50 and 250, 250 and $500 \mathrm{~km}$, respectively, from the focal company, but in the same country as the company. Similarly, IVCavailability_abroad_0_500_ $\mathrm{km}$ is the log of the number of new investments made by IVC investors located between 0 and $500 \mathrm{~km}$ from the focal company and in different countries. In the same way, we generate GVCavailability_national_0_50_km, GVCavailability_national_50_250_km, GVCavailability_national_250 _ $500 \_\mathrm{km}$ and GVCavailability_abroad_ $0 \_500_{-} \mathrm{km}$ for GVC investors.

Regarding VC reputation, we take inspiration from Nahata's (2008) measure of reputation based on the focal VC investor's share of aggregate investments in the VC industry. For each VC firm, we cumulate the number of investments from the beginning of year 1980 to the focal calendar year and normalize it by the overall aggregate number of investments in the VC industry until that year. ${ }^{18}$ We then generate a set of variables reflecting the activism of more reputed VC investors, i.e., those whose reputation in a given year is in the last quartile of the distribution, and a similar set for other VC investors. Specifically, the variables are VCavail_highrep_national_0_50_ $\mathrm{km}$, VCavail_highrep_ national_50_250_km, VCavail_highrep_national_250_500_ $\mathrm{km}$ and VCavail_highrep_abroad_0_500_ $\mathrm{km}$ for more reputed VC investors, and VCavail_lowrep_national_0_50_ $\mathrm{km}, \quad$ VCavail_lowrep_national _50_250_km, VCavail_lowrep_national_250_500_km and VCavail_lowrep_abroad_0_500_ $\mathrm{km}$ for less reputed VC investors.

Results of these additional analyses are shown in Table 6. In column 1 , we focus on IVC investors, finding results that are virtually identical to those of the entire sample: the availability of IVC within national borders and located at distances lower than $250 \mathrm{~km}$ boost the demand for external equity (effects are significant at the $5 \%$ level). Instead, our results in column 2 reveal that for GVC, distance matters more: only GVC investors located within a radius of $50 \mathrm{~km}$ influence the demand for external equity (significant at the $1 \%$ level).

In columns 3 and 4, we split VC investors according to their reputation. For investors with lower reputation (column 3) the general results hold: only the national availability of VC within a radius of less than $250 \mathrm{~km}$ has a positive effect on the demand for external equity (with significances ranging from $1 \%$ to $5 \%$ ). For more reputed VC investors (column 4), these effects though positive, are not significant, possibly as a result of the greater concentration of these investors in a

\footnotetext{
${ }^{18}$ Nahata (2008) uses the invested amount to compute the reputation measure, while we use the number of investments, as in our data there are too may missing values in the investment amounts.
} 
Table 6

Seeking external equity: the effect of the type and reputation of the investors, panel random-effects models.

\begin{tabular}{|c|c|c|c|c|}
\hline & (1) & (2) & (3) & (4) \\
\hline VCavail_IVC_national_0-50_km & $\begin{array}{l}0.015^{\text {** }} \\
(0.007)\end{array}$ & & & \\
\hline VCavail_IVC_national_50-250_km & $\begin{array}{l}0.016^{* *} \\
(0.008)\end{array}$ & & & \\
\hline VCavail_IVC_national_250-500_km & $\begin{array}{l}-0.003 \\
(0.009)\end{array}$ & & & \\
\hline VCavail_IVC_abroad_0-500_km & $\begin{array}{l}0.014 \\
(0.009)\end{array}$ & & & \\
\hline VCavail_GVC_national_0-50_km & & $\begin{array}{l}0.024^{* \ldots * x} \\
(0.009)\end{array}$ & & \\
\hline VCavail_GVC_national_50-250_km & & $\begin{array}{l}0.012 \\
(0.010)\end{array}$ & & \\
\hline VCavail_GVC_national_250-500_km & & $\begin{array}{l}0.002 \\
(0.010)\end{array}$ & & \\
\hline VCavail_GVC_abroad_0-500_km & & $\begin{array}{l}-0.003 \\
(0.008)\end{array}$ & & \\
\hline VCavail_lowrep_national_0-50_km & & & $\begin{array}{l}0.018^{\text {the }} \\
(0.007)\end{array}$ & \\
\hline VCavail_lowrep_national_50-250_km & & & $\begin{array}{l}0.021^{\text {vinte }} \\
(0.008)\end{array}$ & \\
\hline VCavail_lowrep_national_250-500_km & & & $\begin{array}{l}-0.003 \\
(0.008)\end{array}$ & \\
\hline VCavail_lowrep_abroad_0-500_km & & & $\begin{array}{l}0.011 \\
(0.009)\end{array}$ & \\
\hline VCavail_highrep_national_0-50_km & & & & $\begin{array}{l}0.005 \\
(0.008)\end{array}$ \\
\hline VCavail_highrep_national_50-250_km & & & & $\begin{array}{l}0.010 \\
(0.007)\end{array}$ \\
\hline VCavail_highrep_national_250-500_km & & & & $\begin{array}{c}-0.012 \\
(0.007)\end{array}$ \\
\hline VCavail_highrep_abroad_0-500_km & & & & $\begin{array}{l}0.014^{* * *} \\
(0.007)\end{array}$ \\
\hline age & $\begin{array}{l}0.047^{* * x k} \\
(0.016)\end{array}$ & $\begin{array}{l}0.047^{\text {(k) }} \\
(0.016)\end{array}$ & $\begin{array}{l}0.046^{\text {tent }} \\
(0.016)\end{array}$ & $\begin{array}{l}0.048 \\
(0.016)\end{array}$ \\
\hline Constant & $\begin{array}{l}-0.688 \\
(0.459)\end{array}$ & $\begin{array}{l}-0.420 \\
(0.423)\end{array}$ & $\begin{array}{c}-0.667 \\
(0.450)\end{array}$ & $\begin{array}{c}-0.711 \\
(0.441)\end{array}$ \\
\hline Year dummies & Yes & Yes & Yes & Yes \\
\hline Country dummies & Yes & Yes & Yes & Yes \\
\hline Industry dummies & Yes & Yes & Yes & Yes \\
\hline HC variables & Yes & Yes & Yes & Yes \\
\hline Local variables & Yes & Yes & Yes & Yes \\
\hline Accounting variables & Yes & Yes & Yes & Yes \\
\hline $\mathrm{N}$ observations & 3412 & 3412 & 3412 & 3412 \\
\hline $\mathrm{N}$ groups & 404 & 404 & 404 & 404 \\
\hline $\mathrm{R} 2$ & 0.06 & 0.06 & 0.06 & 0.06 \\
\hline
\end{tabular}

The table reports coefficients and standard errors (in brackets) of panel random effects models whose dependent variable is VCseeking.

Significance levels: ${ }^{*} p<0.10$.

** Significance levels: $p<0.05$.

$* * *$ Significance levels: $p<0.01$.

few hubs. ${ }^{19}$ Interestingly, for these investors, we find a positive effect of the cross-border availability of VC: VCavail_highrep_abroad _ $0 \_50{ }_{-} \mathrm{km}$ has a positive and significant coefficient at the $5 \%$ level. An increase of 20 new investments outside of the country and within $500 \mathrm{~km}$ from the location of a focal company leads to a 3.2 percentagepoint increase in the probability that the company under consideration will look for external equity (an increase of almost one sixth of the unconditional probability).

Finally, we study how cultural and institutional distance between the country of the focal company and the one of prospective VC investors affects the demand for external equity and its relationship with

\footnotetext{
${ }^{19}$ More than $50 \%$ of the investments of more reputed VC investors are concentrated in the London areas and almost 80 percent are concentrated in four VC hubs.
}

geographical distance. We replace VCavailability_abroad_0_500_ $\mathrm{km}$ with measures capturing the VC availability abroad in countries that are culturally far from or close to the country of the focal company. VCavail_culturefar_0_500_ $k \mathrm{~m}$ and VCavail_cultureclose_0_500_km are equal to the log of the number of new investments made by VC investors located between 0 and $500 \mathrm{~km}$ from the focal company and in a country that is culturally far from and close to the country of the focal company, respectively. We measure cultural distance based on Drogendijk and Slangen (2006). For all countries, we retrieve the 4 dimensions of cultural distance originally identified by Hofstede: power distance, uncertainty avoidance, individualism and masculinity. Then, we compute an overall measure of cultural distance as follows:

$$
\begin{aligned}
& \text { CulturalDistance }_{c, g} \\
& =\frac{1}{4} \sum_{d=1}^{4} \frac{\left(\text { CulturalDimension }_{c}^{d}-\text { CulturalDimension }_{g}^{d}\right)^{2}}{\mathrm{SD}\left(\text { CulturalDimension }^{d}\right)}
\end{aligned}
$$

where $d$ is one of the four dimensions of cultural distance, $c$ is the country of the focal company and $g$ is the country of the prospective VC investor. SD is the standard deviation of the dimensions across countries. We consider as "culturally far" those pairs of countries for which the cultural distance is higher than the first quartile and as "culturally close" the other pairs of countries.

Similarly, we study the effect of institutional distance on the relationship between availability of VC and demand for external equity. For each country, we retrieve information from the World Governance Index database (Mastruzzi et al., 2007) on six indexes capturing different institutional dimensions: voice and accountability, political stability, government effectiveness, regulatory quality, rule of law and control of corruption. Similarly to Li and Zahra (2012), we compute the level of formal institutional development in each country with a principal component analysis on the six indexes. The principal components analysis indicates that the first component accounts for $85.14 \%$ of the total variance and is calculated as Institutional Development $=[$ Voice Accountability $\times 0.3904+$ Political Stability $\times 0.3643+$ Government effectiveness $\times 0.4245+$ Regulatory Quality $\times 0.4132+$ Rule of law $\times$ $0.4312+$ Control of corruption $\times 0.4218]$. Next, we compute the absolute difference between the value of Institutional development of the country of the focal company and that of the country of prospective VC investors and consider as "institutionally far" the pairs of counties for which this difference is higher than the first quartile. Finally, we replace the variable VCavailability_abroad_0_500_ $\mathrm{km}$ alternatively with VCavail_institutionsfar_0_500_km and VCavail_institutionsclose_0_ $500 \_\mathrm{km}$. These variables consider VC availability in countries that are institutionally far from and close to that of the focal company, respectively.

Results on how cultural and institutional differences moderate the relationship between demand for external equity and VC availability are presented in Table 7. In all models, results on the availability of VC within national borders are consistent with those of the main analysis (with a somehow lower significance for the variable VCavailability_national_50_250_ $\mathrm{km}$ ). However, columns 2 and 4 show that when cultural and institutional distances are low, the availability of VC beyond national borders influences the demand for external equity. VCavail_cultureclose_0_500_km in column 2 and VCavail_institutionsclose_0_500_ $\mathrm{km}$ in column 4 are indeed significant at the $10 \%$ and $5 \%$ levels, respectively. In terms of magnitude, the effect is comparable to the one of the VC investments within national borders.

\section{Discussion and conclusion}

The aim of this paper was to assess how the location of entrepreneurial ventures and of prospective VC investors influence 
Table 7

Seeking external equity: the effect of cultural and institutional distance, panel random-effects models.

\begin{tabular}{|c|c|c|c|c|}
\hline & (1) & (2) & (3) & (4) \\
\hline VCavailability_national_0-50_km & $\begin{array}{l}0.018^{\text {t.m }} \\
(0.007)\end{array}$ & $\begin{array}{l}0.016 \\
(0.007)\end{array}$ & $\begin{array}{l}0.018 \\
(0.007)\end{array}$ & $\begin{array}{l}0.014 \\
(0.007)\end{array}$ \\
\hline VCavailability_national_50-250_km & $\begin{array}{l}0.016^{*} \\
(0.008)\end{array}$ & $\begin{array}{l}0.015^{k} \\
(0.008)\end{array}$ & $\begin{array}{l}0.014^{k} \\
(0.008)\end{array}$ & $\begin{array}{l}0.011 \\
(0.008)\end{array}$ \\
\hline VCavailability_national_250-500_km & $\begin{array}{l}-0.002 \\
(0.009)\end{array}$ & $\begin{array}{l}-0.002 \\
(0.008)\end{array}$ & $\begin{array}{l}-0.002 \\
(0.008)\end{array}$ & $\begin{array}{l}-0.001 \\
(0.009)\end{array}$ \\
\hline VCavail_culturefar_0-500_km & $\begin{array}{l}0.006 \\
(0.009)\end{array}$ & & & \\
\hline VCavail_cultureclose_0-500_km & & $\begin{array}{l}0.015^{*} \\
(0.009)\end{array}$ & & \\
\hline VCavail_institutionsfar_0-500_km & & & $\begin{array}{l}0.012 \\
(0.009)\end{array}$ & \\
\hline VCavail_institutionsclose_0-500_km & & & & $\begin{array}{l}0.016^{\text {k*** }} \\
(0.007)\end{array}$ \\
\hline age & $\begin{array}{l}0.046^{\text {k. }} \\
(0.016)\end{array}$ & $\begin{array}{l}0.047^{\text {texts }} \\
(0.016)\end{array}$ & $\begin{array}{l}0.046^{\text {t.*x }} \\
(0.016)\end{array}$ & $\begin{array}{l}0.046^{\text {*2* }} \\
(0.016)\end{array}$ \\
\hline Constant & $\begin{array}{l}-0.626 \\
(0.459)\end{array}$ & $\begin{array}{l}-0.590 \\
(0.458)\end{array}$ & $\begin{array}{l}-0.645 \\
(0.459)\end{array}$ & $\begin{array}{l}-0.513 \\
(0.460)\end{array}$ \\
\hline Year dummies & Yes & Yes & Yes & Yes \\
\hline Country dummies & Yes & Yes & Yes & Yes \\
\hline Industry dummies & Yes & Yes & Yes & Yes \\
\hline HC variables & Yes & Yes & Yes & Yes \\
\hline Local variables & Yes & Yes & Yes & Yes \\
\hline Accounting variables & Yes & Yes & Yes & Yes \\
\hline $\mathrm{N}$ observations & 3412 & 3412 & 3412 & 3412 \\
\hline N groups & 404 & 404 & 404 & 404 \\
\hline $\mathrm{R} 2$ & 0.06 & 0.06 & 0.06 & 0.06 \\
\hline
\end{tabular}

The table reports coefficients and standard errors (in brackets) of panel random effects models whose dependent variable is VCseeking.

* Significance levels: $p<0.10$.

** Significance levels: $p<0.05$.

$* * *$ Significance levels: $p<0.01$.

ventures' propensity to look for external equity. For this purpose, we have examined the external equity-seeking behaviour of a sample of 533 European high-tech entrepreneurial ventures, which we observe during their first 15 years of existence in an unbalanced panel covering a 25-year period (1984-2009). Our results indicate that the positive effect of the availability of VC on ventures' propensity to look for external equity decreases with geographical distance from prospective VC investors and becomes negligible at a distance greater than $250 \mathrm{~km}$. It is also negligible when crossing national borders, independently of geographic distance. Moreover, we show that the distance decay of the stimulating effect of the availability of VC on the demand for external equity depends on the ownership and governance of VC investors and their reputation. The positive effect operates at longer distance for IVC investors (up to $250 \mathrm{~km}$ ) than for GVC investors (up to $50 \mathrm{~km}$ ). Moreover, highly reputed investors, contrary to other investors, can spur demand for external equity even in companies located in other countries (in a radius of $500 \mathrm{~km}$ from their premises). Our findings also suggest that national borders represent a less powerful barrier for the demand for external equity when entrepreneurs and prospective VC investors are located in countries at close cultural and institutional distance. Finally, we find that ventures' external equity-seeking behaviour is not significantly affected by the level of competition in the local VC market.

These results make several original contributions to the literature. In recent years, the entrepreneurial finance literature has devoted considerable attention to the "geography of VC", i.e., the spatial distribution of VC investments. The uneven distribution of VC investments is typically attributed to supply-side factors, such as the strong geographic concentration of VC investors and their inclination to invest locally (Chen et al., 2010; Cumming and Dai, 2010; Lindgaard Christensen, 2007; Mason and Harrison, 2002; Sorenson and Stuart, 2001). We contribute to this literature by arguing and empirically documenting that the uneven distribution of VC investors strongly influences the demand side of the VC market (for a similar claim, see Bertoni et al., 2016; Mason and Harrison, 2002). Our results are in accordance with the view that entrepreneurs located at longer distance from prospective VC investors anticipate higher costs and lower benefits associated with obtaining VC. This reduces their inclination to seek external equity. We show that like VC investors, entrepreneurs exhibit a local bias and prefer to raise equity from investors located nearby. VC investors tend to follow the "20-minutes rule", according to which if a start-up company is not within a 20-min drive of their offices, it will not be funded (Cumming and Dai, 2010). Entrepreneurs' local bias seems to be weaker: entrepreneurs' demand for external equity is influenced by prospective VC investors located up to $250 \mathrm{~km}$ away. Moreover, the strength of the local bias of entrepreneurs depends on the characteristics of prospective VC investors. Our results suggest that entrepreneurs correctly anticipate the differential benefits and costs of different types of investors. Previous studies show that investments by governmental VC investors have a more limited positive impact on portfolio companies than those of private VC investors (Alperovych et al., 2015; Bertoni and Tykvová, 2015; Brander et al., 2015; Cumming et al., 2017; Grilli and Murtinu, 2014). Accordingly, the positive stimulus of the availability of VC on entrepreneurs' demand for external equity vanishes at shorter distance when prospective VC investors are government-owned. As to more reputed VC investors, our results are less clear-cut. Nevertheless, the finding that the presence of reputed VC investors influences the demand for external equity of companies located abroad is in line with previous studies that highlight the greater benefits of backing by reputed VC investors (Hsu, 2004; Nahata, 2008; Sorensen, 2007). These results contribute to the vast and scattered literature that studies the heterogeneity of VC investors (for a review, see Da Rin et al., 2013).

We also add to the literature on cross-border VC investments. This literature highlights the benefits entrepreneurial ventures can reap from partnering with international VC investors, who may offer them access to their local product market and better exit opportunities (Bertoni and Groh, 2014; Mäkelä and Maula, 2005). However, international VC investments may imply substantial costs for entrepreneurial ventures, because of the cultural and institutional differences between the ventures and the investors' countries (Cumming and Macintosh, 2003; Wright et al., 2005). In line with this view, we show that the availability of VC beyond ventures' national borders does not have any stimulating effect on ventures' propensity to look for external equity, unless VC investors are located in countries at close institutional and cultural distance from the country of the venture. Highly reputed VC investors, for which the anticipated benefits are arguably higher, represent an exception, as mentioned above.

Finally, we contribute to the literature on the external financeseeking behaviour of entrepreneurial ventures, focussing on the search for external equity. Consistent with the "pecking order" hypothesis (Myers, 1984), the literature has shown that entrepreneurial ventures are often reluctant to look for external equity (Cosh et al., 2009). Still, a flourishing demand for external equity is fundamental for the development of a "thick", efficient and developed VC industry (Bertoni et al., 2018). Therefore, the investigation of factors that make entrepreneurial 
ventures more or less inclined to look for external equity is of paramount importance. Even after controlling for several company-specific factors highlighted by previous studies (Cosh et al., 2009; Eckhardt et al., 2006; Mina et al., 2013), our findings reveal that entrepreneurial ventures' demand for external equity is strongly influenced by their geographical location and notably their distance from prospective VC investors, a factor that so far has remained almost unexplored (for a partial exception, see Bertoni et al., 2018).

As with any study, ours has some limitations that open new directions for future research. First, by aggregating the number of VC investments based on their distance from the focal company, we lose granularity of information on the territorial density of VC investors. In particular, we are not able to assess whether there is a minimum size for VC hubs to spur demand, or whether on the contrary there are saturation effects over a certain size threshold. Second, although we show that the distance from prospective VC investors influences the demand for external equity of entrepreneurial ventures, we do not know how far entrepreneurial ventures actually sought external equity and from which investors. Obtaining this information would allow to develop a more comprehensive understanding of the demand for VC financing. Third, our study fails to detect any stimulating effect on ventures' external equity-seeking behaviour of the level of competition in local VC markets. Following a consolidated tradition in the industrial organization literature, we inversely proxy the level of competition with industry concentration. More precise measures of the level of competition are probably needed to fully grasp its effects on ventures' demand for external equity. For example, our measure does not consider syndication, which may attenuate the competition between VC investors. Hence, more work is needed for a better understanding of this important issue. Fourth, we assumed that the effect of geographical distance on companies' demand for external equity was stable over the 25year period considered in this study. However, the rapid development of information and communication technologies may have led to a reduction in the importance of the physical proximity between prospective VC investors and entrepreneurs in inducing the latter to seek external equity. It would be interesting to assess how the advanced telecommunications infrastructure moderates the effect of geographical distance on entrepreneurs' demand for VC. In order to do so, more recent data on the demand for external equity would be needed. Such data would also allow us to consider the effects of the recent trends in VC financing. According to Kenney and Zysman (2018), the VC ecosystem has profoundly changed in recent years, especially in the US. In particular, equity supply has increased both in amount and sources, in parallel with a surge in the number of new ventures, especially platform-based start-ups. These phenomena are likely to have changed both the cost of obtaining equity and the need for capital of new ventures, and in turn the demand for external equity.

Despite the limitations above, our study provides novel results that have important policy implications. By showing that geographical distance from prospective VC investors discourages entrepreneurs' search for $\mathrm{VC}$, we bring to the fore the issue of how to spur demand for VC of promising ventures located in peripheral areas. Here, we highlight two possible policy approaches to tackle this issue.

The first approach involves the supply-side, i.e., VC investors themselves. Our results suggest that a more widespread distribution of VC investors across Europe would stimulate the demand for external equity (and VC) of European ventures. Our findings indicate that VC hubs spur demand for external equity in a radius of $250 \mathrm{~km}$. Envisaging the creation of enough VC hubs to stimulate the demand for external equity from promising ventures across Europe, regardless of their location, is a very ambitious policy. Still, the French government took successful steps in this direction. In recent years, BPIfrance (www. bpifrance.fr), the French governmental program supporting entrepreneurial ventures, has favoured the creation of medium sized VC hubs outside the Paris area, e.g., around Lyon, Grenoble, Montpellier, Toulouse and Marseille. ${ }^{20}$

The alternative "demand-side" policy approach would be to make entrepreneurs less reluctant to seek external equity at long distance and across national borders. For this purpose, it is important to diffuse information and increase the awareness of entrepreneurs about the benefits of external equity finance for the development of their businesses. The Finance \& Business Programme in North East England is a good example of such "investment readiness" initiatives (Mason and Harrison, 2001; Mason and Kwok, 2010).

Another politically sensitive result of this paper is that national borders represent a barrier to the demand for VC (except in the case of very reputable VC investors), but that cultural and institutional proximity alleviates this barrier. This result confirms the detrimental effects of the national fragmentation of the European VC market on ventures' demand for external equity. As cultural traits are difficult to change, policy makers should concentrate effort on reducing the institutional distance across European countries. In recent years, the European Commission has taken several steps to overcome national barriers to cross-border VC flows, most notably through the introduction of the VC passport (European Parliament, 2013). Our study indicates that these developments are steps in the right direction. A replication of our analysis with more recent data would allow to assess the alleged positive effects of these regulatory changes on the creation of a unified European VC market.

\section{Appendix A. Calibration of the distance decay parameters}

In this section, we describe the procedure followed to identify the calibrated values for the distance decay parameters, $\alpha$, used to compute the variables VCavailability_national and VCavailability_abroad.

We computed different versions of VCavailability _national (depending on $\alpha_{1}$ ) and VCavailability_abroad (depending on $\alpha_{2}$ ), using values for $\alpha_{1}$ and $\alpha_{2}$ ranging from 0.1 to 2 and in increments of 0.1 . We let both $\alpha$ parameters vary simultaneously, creating a matrix for the combinations of VCavailability_national and VCavailability_abroad. For each combination, we performed a likelihood ratio (LR) test as follows: $L R=-2\left[\log _{-}\right.$-likelihood (unrestricted model) - log-likelihood (restricted model)]. We picked the values of $\alpha_{1}$ and $\alpha_{2}$ that maximize the LR test. The unrestricted model is similar to the model shown in column 2 of Table 4, in which VCavailability_national and VCavailability_abroad are computed using the different values of $\alpha_{1}$ and $\alpha_{2}$. Conversely, in the restricted model, both the variable VCavailability _national and VCavailability_abroad are excluded from the list of regressors. The results of the calibration procedure are shown in Fig. A1. The values that maximize the LR test's $\chi^{2}(2)$ (red area) are 1 and 0.3 for $\alpha_{1}$ and $\alpha_{2}$, respectively. We used those parameters to compute the variables VCavailability_national and VCavailability _abroad used in our analysis.

\footnotetext{
${ }^{20}$ See http://www.lafrenchtech.com/carte. See also https://www.economist.com/finance-and-economics/2018/01/18/the-french-government-experiments-withventure-capitalism, accessed on 22 October 2018.
} 
Table A1

Seeking external equity: robustness checks with radius specification, panel random-effects models.

\begin{tabular}{|c|c|c|c|c|c|c|c|}
\hline & $\begin{array}{l}\text { (1) } \\
\text { Without firms } \\
\text { seeking at } \\
\text { foundation }\end{array}$ & $\begin{array}{l}\text { (2) } \\
\text { Without firms } \\
\text { not needing }\end{array}$ & $\begin{array}{l}\text { (3) } \\
\text { On matched } \\
\text { sample }\end{array}$ & $\begin{array}{l}\text { (4) } \\
\text { Without VC- } \\
\text { backed firms }\end{array}$ & $\begin{array}{l}(5) \\
\text { With IMR on } \\
\text { response }\end{array}$ & $\begin{array}{l}(6) \\
\text { Excluding } \\
\text { bubble period }\end{array}$ & $\begin{array}{l}\text { (7) } \\
\text { Using invested- } \\
\text { firm location }\end{array}$ \\
\hline VCavailability_national_0-50_km & $\begin{array}{l}0.018^{\text {nkx }} \\
(0.008)\end{array}$ & $\begin{array}{l}0.014 \\
(0.010)\end{array}$ & $\begin{array}{l}0.028^{*} \\
(0.015)\end{array}$ & $\begin{array}{l}0.013^{*} \\
(0.007)\end{array}$ & $\begin{array}{l}0.016^{* k * k} \\
(0.006)\end{array}$ & $\begin{array}{l}0.014^{*} \\
(0.008)\end{array}$ & \\
\hline VCavailability_national_50-250_km & $\begin{array}{l}0.008 \\
(0.008)\end{array}$ & $\begin{array}{l}0.017 \\
(0.011)\end{array}$ & $\begin{array}{l}0.008 \\
(0.018)\end{array}$ & $\begin{array}{l}0.016^{* x} \\
(0.007)\end{array}$ & $\begin{array}{l}0.021^{\text {knkth }} \\
(0.007)\end{array}$ & $\begin{array}{l}0.015^{*} \\
(0.008)\end{array}$ & \\
\hline VCavailability_national_250-500_km & $\begin{array}{l}-0.006 \\
(0.009)\end{array}$ & $\begin{array}{l}-0.003 \\
(0.012)\end{array}$ & $\begin{array}{l}-0.027 \\
(0.018)\end{array}$ & $\begin{array}{l}-0.004 \\
(0.008)\end{array}$ & $\begin{array}{l}-0.000 \\
(0.008)\end{array}$ & $\begin{array}{l}-0.007 \\
(0.009)\end{array}$ & \\
\hline VCavailability_abroad_0-500_km & $\begin{array}{l}0.015 \\
(0.009)\end{array}$ & $\begin{array}{l}0.018 \\
(0.013)\end{array}$ & $\begin{array}{l}0.030 \\
(0.021)\end{array}$ & $\begin{array}{l}0.009 \\
(0.009)\end{array}$ & $\begin{array}{l}0.009 \\
(0.007)\end{array}$ & $\begin{array}{l}0.011 \\
(0.010)\end{array}$ & \\
\hline $\begin{array}{l}\text { VCavailability_national_0-50_km (using } \\
\text { invested-companies location) }\end{array}$ & & & & & & & $\begin{array}{l}0.007 \\
(0.006)\end{array}$ \\
\hline $\begin{array}{l}\text { VCavailability_national_50-250_km (using } \\
\text { invested-companies location) }\end{array}$ & & & & & & & $\begin{array}{l}0.021^{\text {k* }} \\
(0.008)\end{array}$ \\
\hline $\begin{array}{l}\text { VCavailability_national_250-500_km (using } \\
\text { invested-companies location) }\end{array}$ & & & & & & & $\begin{array}{l}0.007 \\
(0.008)\end{array}$ \\
\hline $\begin{array}{l}\text { VCavailability_abroad_0-500_km (using } \\
\text { invested-companies location) }\end{array}$ & & & & & & & $\begin{array}{l}0.012 \\
(0.009)\end{array}$ \\
\hline age & $\begin{array}{l}0.073^{\text {kxtele }} \\
(0.023)\end{array}$ & $\begin{array}{l}0.070^{\text {*wak }} \\
(0.023)\end{array}$ & $\begin{array}{l}0.093^{2 k \cdot k} \\
(0.032)\end{array}$ & $\begin{array}{l}0.041^{* * x} \\
(0.016)\end{array}$ & $\begin{array}{l}0.073^{k * * *} \\
(0.015)\end{array}$ & $\begin{array}{l}0.048^{\text {t.3.ke }} \\
(0.018)\end{array}$ & $\begin{array}{l}0.047^{\text {*nte }} \\
(0.016)\end{array}$ \\
\hline Inverse Mills Ratio & & & & & $\begin{array}{l}-0.588^{* \ldots * t} \\
(0.033)\end{array}$ & & \\
\hline Constant & $\begin{array}{l}-0.318 \\
(0.491)\end{array}$ & $\begin{array}{l}-0.941 \\
(0.613)\end{array}$ & $\begin{array}{l}-2.015^{*} \\
(1.055)\end{array}$ & $\begin{array}{l}-0.509 \\
(0.469)\end{array}$ & $\begin{array}{l}0.616 \\
(0.434)\end{array}$ & $\begin{array}{l}-0.595 \\
(0.485)\end{array}$ & $\begin{array}{l}-0.880^{* * *} \\
(0.438)\end{array}$ \\
\hline Year dummies & Yes & Yes & Yes & Yes & Yes & Yes & Yes \\
\hline Country dummies & Yes & Yes & Yes & Yes & Yes & Yes & Yes \\
\hline Industry dummies & Yes & Yes & Yes & Yes & Yes & Yes & Yes \\
\hline $\mathrm{HC}$ variables & Yes & Yes & Yes & Yes & Yes & Yes & Yes \\
\hline Local variables & Yes & Yes & Yes & Yes & Yes & Yes & Yes \\
\hline Accounting variables & Yes & Yes & Yes & Yes & Yes & Yes & Yes \\
\hline $\mathrm{N}$ observations & 2867 & 2314 & 1048 & 2801 & 3412 & 2922 & 3412 \\
\hline $\mathrm{N}$ groups & 329 & 307 & 258 & 264 & 404 & 381 & 404 \\
\hline $\mathrm{R} 2$ & 0.06 & 0.07 & 0.12 & 0.08 & 0.14 & 0.05 & 0.06 \\
\hline
\end{tabular}

Standard errors in parentheses.

The table reports coefficients and standard errors (in brackets) of panel random effects models whose dependent variable is VCseeking.

* Significance levels: $p<0.10$.

** Significance levels: $p<0.05$.

$* * *$ Significance levels: $p<0.01$.

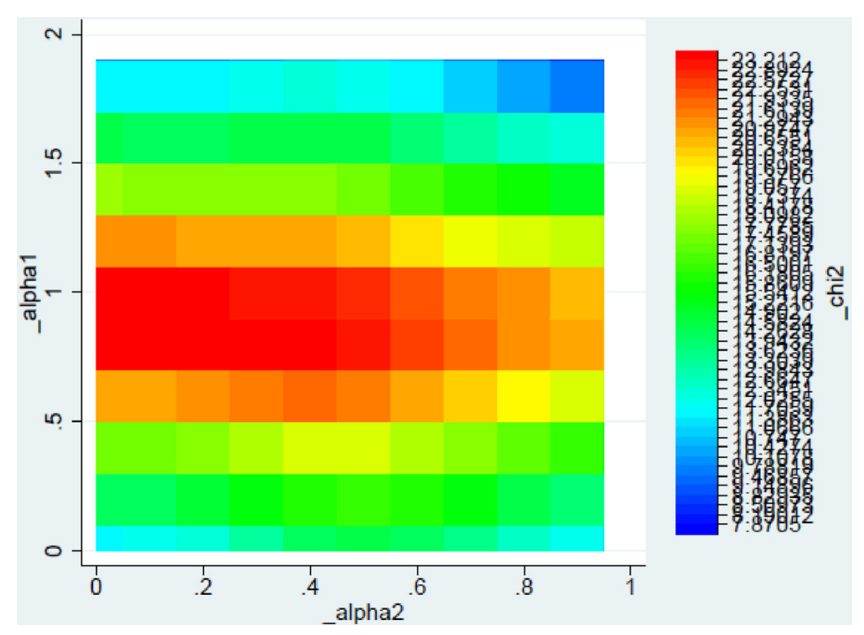

fig. A1. Calibration of the decay parameters for distance. 


\section{References}

Akerlof, G.A., 1970. The market for "lemons": quality uncertainty and the market mechanism. Q. J. Econ. 84, 488-500. https://doi.org/10.2307/1879431.

Alperovych, Y., Hübner, G., Lobet, F., 2015. How does governmental versus private venture capital backing affect a firm's efficiency? Evidence from Belgium. J. Bus. Ventur. 30, 508-525. https://doi.org/10.1016/j.jbusvent.2014.11.001.

Armour, J., Cumming, D.J., 2008. Bankruptcy law and entrepreneurship. Am. Law Econ. Rev. 10, 303-350. https://doi.org/10.1093/aler/ahn008.

Armour, J., Cumming, D.J., 2006. The legislative road to Silicon Valley. Oxf. Econ. Pap. 58, 596-635. https://doi.org/10.1093/oep/gpl007.

Audretsch, D.B., Stephan, P.E., 1996. Company-scientist locational links: the case of biotechnology. Am. Econ. Rev. https://doi.org/10.2307/2118217.

Bernstein, S., Giroud, X., Townsend, R., 2016. The impact of venture capital monitoring. J. Finan. 71, 1591-1622. https://doi.org/10.1111/jofi.12370.

Bertoni, F., Colombo, M.G., Quas, A., 2015. The patterns of venture capital investment in Europe. Small Bus. Econ. 45, 543-560. https://doi.org/10.1007/s11187-015-9662-0.

Bertoni, F., D'Adda, D., Grilli, L., 2018. Self-selection of entrepreneurial firms in thin venture capital markets: theory and empirical evidence. Strateg. Entrep. J. 1-34. https://doi.org/10.1111/sej.1280. In press.

Bertoni, F., D'Adda, D., Grilli, L., 2016. Cherry-picking or frog-kissing? A theoretical analysis of how investors select entrepreneurial ventures in thin venture capital markets. Small Bus. Econ. 46, 391-405. https://doi.org/10.1007/s11187-0159690-9.

Bertoni, F., Groh, A.P., 2014. Cross-border investments and venture capital exits in Europe. Corp. Gov. An Int. Rev. 22, 84-99. https://doi.org/10.1111/corg.12056.

Bertoni, F., Martí, J., 2011. Financing Entrepreneurial Ventures in Europe: The Vico Dataset, SSRN eLibrary, SSRN eLibrary No.1939855. https://doi.org/10.2139/ssrn. 1904297.

Bertoni, F., Tykvová, T., 2015. Does governmental venture capital spur invention and innovation? Evidence from young European biotech companies. Res. Policy 44 925-935. https://doi.org/10.1016/j.respol.2015.02.002.

Bonaccorsi, A., Colombo, M.G., Guerini, M., Rossi-Lamastra, C., 2014. The impact of local and external university knowledge on the creation of knowledge-intensive firms: evidence from the Italian case. Small Bus. Econ. 43, 261-287. https://doi.org/10. 1007/s11187-013-9536-2.

Brander, J.A., Du, Q., Hellmann, T.F., 2015. The effects of government-sponsored venture capital: international evidence. Rev. Finan. 19, 571-618. https://doi.org/10.1093/ rof/rfu009.

Brav, O., 2009. Access to capital, capital structure, and the funding of the firm. J. Finan. 64, 263-308. https://doi.org/10.1111/j.1540-6261.2008.01434.x.

Bruno, A.V., Tyebjee, T.T., 1985. The entrepreneur's search for capital. J. Bus. Ventur. 1, 61-74. https://doi.org/10.1016/0883-9026(85)90007-2.

Burchardt, J., Hommel, U., Kamuriwo, D.S., Billitteri, C., 2016. Venture capital contracting in theory and practice: implications for entrepreneurship research. Entrep. Theory Pract. 40, 25-48. https://doi.org/10.1111/etap.12104.

Carpenter, R.E., Petersen, B.C., 2002. Capital market imperfections, high-tech investment, and new equity financing. Econ. J. 112, F54-F72. https://doi.org/10.1111/14680297.00683.

Carpentier, C., Suret, J.-M., 2006. Some evidence of the external financing costs of new technology-based firms in Canada. Ventur. Cap. 8, 227-252. https://doi.org/10. 1080/13691060600748421.

Chen, H., Gompers, P.A., Kovner, A., Lerner, J., 2010. Buy local? The geography of venture capital. J. Urban Econ. 67, 90-102. https://doi.org/10.1016/j.jue.2009.09. 013.

Cosh, A., Cumming, D.J., Hughes, A., 2009. Outside entrepreneurial capital. Econ. J. 119, 494-533. https://doi.org/10.1111/j.1468-0297.2009.02270.x.

Cumming, D.J., Dai, N., 2010. Local bias in venture capital investments. J. Empir. Finan. 17, 362-380. https://doi.org/10.1016/j.jempfin.2009.11.001.

Cumming, D.J., Grilli, L., Murtinu, S., 2017. Governmental and independent venture capital investments in Europe: a firm-level performance analysis. J. Corp. Finan. 42, 439-459. https://doi.org/10.1016/j.jcorpfin.2014.10.016.

Cumming, D.J., Macintosh, J.G., 2003. A cross-country comparison of full and partial venture capital exits. J. Bank. Finan. 27, 511-548.

Cumming, D.J., Schmidt, D., Walz, U., 2010. Legality and venture capital governance around the world. J. Bus. Ventur. 25, 54-72. https://doi.org/10.1016/j.jbusvent. 2008.07.001.

Da Rin, M., Hellmann, T.F., Puri, M., 2013. A survey of venture capital research. Handb. Econ. Finan. 2, 573-648. https://doi.org/10.1016/B978-0-44-453594-8.00008-2.

Dahl, M.S., Sorenson, O., 2012. Home sweet home: entrepreneurs' location choices and the performance of their ventures. Manage. Sci. 58, 1059-1071. https://doi.org/10. $1287 /$ mnsc. 1110.1476.

Dai, N., Jo, H., Kassicieh, S., 2012. Cross-border venture capital investments in Asia: selection and exit performance. J. Bus. Ventur. 27, 666-684. https://doi.org/10. 1016/j.jbusvent.2011.04.004.

Dale, S.B., Krueger, A.B., 2002. Estimating the payoff to attending a more selective college: an application of selection on observables and unobservables. Q. J. Econ. 117, 1491-1527. https://doi.org/10.1162/003355302320935089.

Dimov, D.P., Gedajlovic, E., 2010. A property rights perspective on venture capital investment decisions. J. Manag. Stud. 47, 1248-1271. https://doi.org/10.1111/j.14676486.2009.00905.x.

Drogendijk, R., Slangen, A., 2006. Hofstede, Schwartz, or managerial perceptions? The effects of different cultural distance measures on establishment mode choices by multinational enterprises. Int. Bus. Rev. 15, 361-380. https://doi.org/10.1016/J. IBUSREV.2006.05.003.
Eckhardt, J.T., Delmar, F., Shane, S., 2006. Multistage selection and the financing of new ventures. Manage. Sci. 52, 220-232. https://doi.org/10.1287/mnsc.1050.0478.

European Commission, 2007. Removing Obstacles to Cross-border Investments by Venture Capital Funds. European Commission, Brussels.

European Parliament, 2013. Regulation (EU) No 345/2013 of the European Parliament and of the Council of 17 April 2013 on European Venture Capital Funds.

Eurostat, 2011. Regions in the European Union: Nomenclature of Territorial Units for Statistics NUTS 2010/EU-27. pp. 195-223. https://doi.org/10.2785/15544.

Fiet, J.O., 1995. Reliance upon informants in the venture capital industry. J. Bus. Ventur. 10, 195-223. https://doi.org/10.1016/0883-9026(94)00039-W.

Fried, V.H., Hisrich, R.D., 1994. Toward a model of venture capital investment decision making. Finan. Manag. 23, 28. https://doi.org/10.2307/3665619.

Gans, J.S., Stern, S., 2010. Is there a market for ideas? Ind. Corp. Change 19, 805-837. https://doi.org/10.1093/icc/dtq023.

Gompers, P.A., Lerner, J., 2001. The Money of Invention: How Venture Capital Creates New Wealth. Harvard Business Press, Boston, MA.

Gompers, P.A., Lerner, J., 2000. Money chasing deals? The impact of fund inflows on private equity valuation. J. Finan. Econ. 55, 281-325. https://doi.org/10.1016/ S0304-405X(99)00052-5.

Gorman, M., Sahlman, W.A., 1989. What do venture capitalists do? J. Bus. Ventur. 4, 231-248. https://doi.org/10.1016/0883-9026(89)90014-1.

Grilli, L., Murtinu, S., 2014. Government, venture capital and the growth of European high-tech entrepreneurial firms. Res. Policy 43, 1523-1543. https://doi.org/10. 1016/j.respol.2014.04.002.

Hall, B.H., Jaffe, A.B., Trajtenberg, M., 2005. Market value and patent citations. RAND J. Econ. 36, 16-38.

Heckman, J.J., 1979. Sample selection bias as a specification error. Econometrica 47 153-161. https://doi.org/10.2307/1912352.

Ho, D.E., Imai, K., King, G., Stuart, E.A., 2007. Matching as nonparametric preprocessing for reducing model dependence in parametric causal inference. Polit. Anal. 15, 199-236. https://doi.org/10.1093/pan/mpl013.

Hsu, D.H., 2004. What do entrepreneurs pay for venture capital affiliation? J. Finan. 59, 1805-1844. https://doi.org/10.1111/j.1540-6261.2004.00680.x.

Kaplan, S.N., Strömberg, P., 2003. Financial contracting theory meets the real world: an empirical analysis of venture capital contracts. Rev. Econ. Stud. 70, 281-315. https:// doi.org/10.1111/1467-937X.00245.

Kaplan, S.N., Strömberg, P., 2001. Venture capitalists as principals: contracting, screening, and monitoring. Am. Econ. Rev. 91, 426-430. https://doi.org/10.3386/ w8202.

Kenney, M., Zysman, J., 2018. Unicorns, Cheshire cats, and the new dilemmas of entrepreneurial finance. Ventur. Cap. Int. J. Entrep. Finan. 1-20. https://doi.org/10. 1080/13691066.2018.1517430.

Lerner, J., 1995. Venture Capitalists and the Oversight of Private Firms 50. pp. 301-318.

Li, Y., Vertinsky, I.B., Li, J., 2014. National distances, international experience, and venture capital investment performance. J. Bus. Ventur. 29, 471-489. https://doi org/10.1016/j.jbusvent.2013.08.002.

Li, Y., Zahra, S.A., 2012. Formal institutions, culture, and venture capital activity: a crosscountry analysis. J. Bus. Ventur. 27, 95-111. https://doi.org/10.1016/j.jbusvent. 2010.06.003.

Lindgaard Christensen, J., 2007. The development of geographical specialization of venture capital. Eur. Plan. Stud. 15, 817-833. https://doi.org/10.1080/ 09654310701232137.

Mäkelä, M.M., Maula, M.V.J., 2005. Cross-border venture capital and new venture in ternationalization: an isomorphism perspective. Ventur. Cap. 7, 227-257. https:// doi.org/10.1080/13691060500258877.

Martin, R., Berndt, C., Klagge, B., Sunley, P., 2005. Spatial proximity effects and regional equity gaps in the venture capital market: evidence from Germany and the United Kingdom. Environ. Plan. A 37, 1207-1231. https://doi.org/10.1068/a3714.

Mason, C.M., Harrison, R.T., 2002. The geography of venture capital investments in the UK. Trans. Inst. Br. Geogr. 27, 427-451. https://doi.org/10.1111/1475-5661.00064.

Mason, C.M., Harrison, R.T., 2001. "Investment readiness": a critique of government proposals to increase the demand for venture capital. Reg. Stud. 35, 663-668. https://doi.org/10.1080/00343400120075939.

Mason, C.M., Kwok, J., 2010. Investment Readiness Programmes and Access to Finance: A Critical Review of Design Issues. Local Econ.

Mastruzzi, M., Kraay, A., Kaufmann, D., 2007. Governance Matters VI: Aggregate and Individual Governance Indicators, 1996-2006, Policy Research Working Papers. The World Bankhttps://doi.org/10.1596/1813-9450-4280.

Michelacci, C., Silva, O., 2007. Why so many local entrepreneurs? Rev. Econ. Stat. 89, 615-633. https://doi.org/10.1162/rest.89.4.615.

Mina, A., Lahr, H., Hughes, A., 2013. The demand and supply of external finance for innovative firms. Ind. Corp. Change 22, 869-901. https://doi.org/10.1093/icc/ dtt020.

Myers, S.C., 1984. Capital Structure Puzzle. J. Finan., NBER working Paper Series 39. pp. 575-592.

Nahata, R., 2008. Venture capital reputation and investment performance. J. Finan. Econ. 90, 127-151. https://doi.org/10.1016/j.jfineco.2007.11.008.

Nahata, R., Hazarika, S., Tandon, K., 2015. Success in global venture capital investing: do institutional and cultural differences matter? J. Finan. Quant. Anal. 49, 1039-1070. https://doi.org/10.1017/S0022109014000568.

Ou, C., Haynes, G.W., 2006. Acquisition of additional equity capital by small firms findings from the national survey of small business finances. Small Bus. Econ. 27, 157-168. https://doi.org/10.1007/s11187-006-0009-8.

Petty, J.S., Gruber, M., 2011. "In pursuit of the real deal". A longitudinal study of VC decision making. J. Bus. Ventur. 26, 172-188. https://doi.org/10.1016/j.jbusvent 2009.07.002. 
Pollock, T.G., Lee, P.M., Jin, K., Lashley, K., 2015. (Un)tangled: exploring the asymmetric coevolution of new venture capital firms' reputation and status. Adm. Sci. Q. 60, 482-517. https://doi.org/10.1177/0001839215585602.

Roth, A.E., 2008. What have we learned from market design? Econ. J. 118, 285-310. https://doi.org/10.1111/j.1468-0297.2007.02121.x.

Sapienza, H.J., 1992. When do venture capitalists add value? J. Bus. Ventur. 7, 9-27.

Schertler, A., Tykvova, T., 2012. What lures cross-border venture capital inflows? J. Int Money Finan. 31, 1777-1799. https://doi.org/10.1016/j.jimonfin.2012.03.012.

Shane, S., Cable, D., 2002. network ties, reputation, and the financing of new ventures. Manag. Sci. 48, 364-381. https://doi.org/10.1287/mnsc.48.3.364.7731.

Sorensen, M., 2007. How smart is smart money? A two-sided matching model of venture capital. J. Finan. 62, 2725-2762. https://doi.org/10.1111/j.1540-6261.2007. 01291.x.

Sorenson, O., Stuart, T.E., 2001. Syndication networks and the spatial distribution of venture capital investments. Am. J. Sociol. 106, 1546-1588. https://doi.org/10. $1086 / 321301$.

Stuart, T.E., Sorenson, O., 2003. The geography of opportunity: spatial heterogeneity in founding rates and the performance of biotechnology firms. Res. Policy 32, 229-253. Vos, E., Yeh, A.J.-Y., Carter, S., Tagg, S., 2007. The happy story of small business financing. J. Bank. Finan. 31, 2648-2672. https://doi.org/10.1016/J.JBANKFIN.2006 09.011.

Wright, M., Pruthi, S., Lockett, A., 2005. International venture capital research: from cross-country comparisons to crossing borders. Int. J. Manag. Rev. 7, 135-165. https://doi.org/10.1111/j.1468-2370.2005.00113.x.

Zucker, L.G., Darby, M.R., Armstrong, J., 1998. Geographically localized knowledge: spillovers or markets? Econ. Inq. 36, 65-86. https://doi.org/10.1111/j.1465-7295. 1998.tb01696.x. 